University of Nebraska - Lincoln

DigitalCommons@University of Nebraska - Lincoln

$7-9-2020$

\title{
Early Paleogene biosiliceous sedimentation in the Atlantic Ocean: Testing the inorganic origin hypothesis for Paleocene and Eocene chert and porcellanite
}

Jakub Witkowski

Donald E. Penman

Karolina Bryłka

Bridget S. Wade

Sabine Matting

See next page for additional authors

Follow this and additional works at: https://digitalcommons.unl.edu/geosciencefacpub

Part of the Paleontology Commons, and the Tectonics and Structure Commons

This Article is brought to you for free and open access by the Earth and Atmospheric Sciences, Department of at DigitalCommons@University of Nebraska - Lincoln. It has been accepted for inclusion in Papers in the Earth and Atmospheric Sciences by an authorized administrator of DigitalCommons@University of Nebraska - Lincoln. 


\section{Authors}

Jakub Witkowski, Donald E. Penman, Karolina Bryłka, Bridget S. Wade, Sabine Matting, David M. Harwood, and Steven M. Bohaty 


\title{
Early Paleogene biosiliceous sedimentation in the Atlantic Ocean: Testing the inorganic origin hypothesis for Paleocene and Eocene chert and porcellanite
}

\author{
Jakub Witkowski, ${ }^{1}$ Donald E. Penman, ${ }^{2}$ Karolina Bryłka, ${ }^{3}$ \\ Bridget S. Wade, ${ }^{4}$ Sabine Matting, ${ }^{5,6}$ David M. Harwood,7 \\ and Steven M. Bohaty ${ }^{8}$
}

1 Institute of Marine and Environmental Sciences, University of Szczecin, ul. Mickiewicza 18, 70-383 Szczecin, Poland

2 Geology and Geophysics, Yale University, 210 Whitney Ave., New Haven, CT o6511, USA

3 Department of Geology, Faculty of Science, Lund University, Sölvegatan 12, Lund, Sweden

4 Department of Earth Sciences, University College London, Gower Street, London WC1E 6BT, United Kingdom

5 Geological Survey of Mecklenburg-Western Pomerania, LUNG M-V, Goldberger Str. 12, 18273 Güstrow, Germany

6 Institute of Geography and Geology, University of Greifswald, F.-L.-Jahn-Str. 15a, 17487 Greifswald, Germany

7 Department of Earth and Atmospheric Sciences, University of NebraskaLincoln, Lincoln, NE 68588-0340, USA

8 Ocean and Earth Science, National Oceanography Centre Southampton, University of Southampton Waterfront Campus, European Way, Southampton SO14 3ZH, UK.

Corresponding author - J. Witkowski; email jakub.witkowski@usz.edu.pl

Published in Palaeogeography, Palaeoclimatology, Palaeoecology 556 (2020) 109896 doi:10.1016/j.palaeo.2020.109896

Copyright (c) 2020 Elsevier B.V. Used by permission.

Submitted 18 February 2020; revised 3 July 2020; accepted 3 July 2020; published 9 July 2020. 


\begin{abstract}
The widespread occurrence of lower Eocene chert and porcellanite has been viewed as a major paleoceanographic issue since the advent of ocean drilling, and both biotic and abiotic forcings have been proposed to explain it. We present a reconstruction of indurated siliceous sediment (ISS) and preserved biosiliceous sediment (PBS) occurrences in the Atlantic Ocean through the Paleocene and Eocene ( 66 through $34 \mathrm{Ma})$. ISS and PBS distributions reveal dissimilar temporal trends, with the peak of ISS occurrences coinciding with the Early Eocene Climatic Optimum, in line with previous studies. PBS occurrences show a generally increasing trend culminating between 44 and $43 \mathrm{Ma}$. The common co-occurrence of ISS and PBS, and their coherent geographic distribution lends strong support to the biogenic origin of the precursor to the widespread Paleogene ISS, and argues against an inorganic mode of early Cenozoic chert and porcellanite precipitation. Weight per cent biogenic opal records and trends in linear sedimentation rates indicate two plausible modes of silicification: 1) silicification due to prolonged exposure of biogenic opal-rich sediments to corrosive bottom waters; and 2) silicification due to elevated pressures and temperatures caused by rapid burial of biogenic opal-rich deposits. The confinement of ISS and PBS to proximal sites along continental margins points to the reliance of siliceous sedimentation through the Paleocene and Eocene on terrestrial supply of dissolved silicon. Consistent with this, quantitative siliceous microfossil assemblage records from the Blake Nose in the NW Atlantic indicate that the nutrient-rich marginal rather than oligotrophic pelagic settings hosted the majority of siliceous plankton production through the early Paleogene. The inorganic $\mathrm{SiO}_{2}$ precipitation model is unlikely to have been the dominant mechanism responsible for ubiquitous occurrences of early Paleogene ISS. We favor the biogenic ISS precursor scenario and reconcile it with the low-productivity early Cenozoic oceans by showing that large volumes of biogenic silica were supplied to the western North Atlantic Ocean from the North American margin through the Paleocene and Eocene. Dissolution of this surplus silica was facilitated by an early southwestward flow of young, SiO2-depleted waters from the North Atlantic. All these factors contributed to ISS and PBS focusing in the western North Atlantic through the early Paleogene.
\end{abstract}

Keywords: Diatoms, Blake Nose, Biogenic silica, Diagenesis, Paleoceanography, Ocean drilling

\title{
1. Introduction
}

The lower Paleocene through upper Eocene (hereafter abbreviated as $\mathrm{P}+\mathrm{E}$ ) deep-sea and onshore sedimentary record shows evidence for widespread $\mathrm{SiO}_{2}$ deposition, including geographically extensive marine and freshwater diatomite (e.g., Oreshkina and Aleksandrova, 2007; Mach and Dvořák, 2011), deep-sea diatom and radiolarian ooze (e.g., Gombos, 1977; Nishimura, 1987), siliceous nannofossil ooze and 
chalk (e.g., Fourtanier, 1991), and chert and porcellanite (e.g., Hein et al., 1990; Muttoni and Kent, 2007). This interval is also the most recent example of a global greenhouse climate, with atmospheric $\mathrm{pCO}_{2}$ levels estimated at 500-1000 ppmv (e.g., Foster et al., 2017) and surface and ocean temperatures approximately $10{ }^{\circ} \mathrm{C}$ higher than modern (e.g., Zachos et al., 2001). In recent years there is a growing interest in the links between the silicon and carbon cycles, and the timescales of marine silica burial response to the extreme climate perturbations of the early Paleogene, with most insights based on modeling and stable isotope geochemistry (e.g., Penman, 2016; Penman et al., 2019; Fontorbe et al., 2020). Reconstructing biogenic silica (hereafter ${ }_{\text {bio }} \mathrm{SiO}_{2}$ ) burial and diagenetic history may help unravel the interplay between weathering regimes, primary production and ocean circulation patterns (e.g., Miskell et al., 1985; Hein and Parrish, 1987; Maliva et al., 1989; McGowran, 1989; Yool and Tyrrell, 2005; Penman, 2016; Penman et al., 2019) through a critically important period of Earth's climate evolution (Zachos et al., 2008; Cramer et al., 2009).

The widespread occurrence of roughly coeval indurated siliceous sediments of early Eocene age often collectively referred to as Horizon $\mathrm{A}^{\mathrm{C}}$ (e.g., Riech and von Rad, 1979; Norris et al., 2001; Boyle et al., 2017) was one of the key targets of early scientific deep-sea drilling (e.g., Ewing et al., 1970). Multiple hypotheses have been put forward to explain the origin of this ubiquitous silicification. Berger (1970) pointed to basin-to-basin ${ }_{\text {bio }} \mathrm{SiO}_{2}$ fractionation by means of lagoonal (Atlantic) versus estuarine (Pacific) circulation. Under this scenario, the Pacific nutrient-rich deep waters favored ${ }_{\text {bio }} \mathrm{SiO}_{2}$ preservation, while the Atlantic nutrient-poor deep waters facilitated ${ }_{\text {bi- }}$ ${ }_{0} \mathrm{SiO}_{2}$ dissolution. Gibson and Towe (1971) postulated diagenetic alteration of pyroclastic material and speculated on its possible effects on siliceous plankton production, whereas Weaver and Wise (1974) argued for an entirely biogenic origin of the chert/porcellanite precursors. More complex models invoking, for instance, reprecipitation of ${ }_{\text {bio }} \mathrm{SiO}_{2}$ leached by advecting hydrothermal waters (Moore, 2008a, 2008b) were also proposed. Two hypotheses that have drawn the most interest, however, were proposed by McGowran (1989) and Muttoni and Kent (2007).

The „silica burp hypothesis” of McGowran (1989) linked the widespread early Paleogene silicification to volcanic $\mathrm{SiO}_{2}$ input, followed 
by enhanced ocean mixing driven by long-term ocean cooling through the Eocene. Silicon cycle modeling by Yool and Tyrell (2005), however, indicated that "silica burp" was not sufficient to explain neither the large volumes of $\mathrm{SiO}_{2}$ making up Horizon $\mathrm{A}^{\mathrm{C}}$, nor the temporal span of the widespread early Paleogene silicification. Instead, Muttoni and Kent (2007) proposed a complex model invoking clay mineral-mediated inorganic precipitation of $\mathrm{SiO}_{2}$ from seawater. One of the main assumptions that Muttoni and Kent (2007) made was that the early Paleogene oceans were characterized by largely oligotrophic conditions. At the same time, Muttoni and Kent (2007) hypothesized there would be an ample supply of $\mathrm{SiO}_{2}$ from terrestrial weathering, accelerated by the extreme greenhouse warmth of the early Paleogene. In a stratified water column, the low supply of additional limiting nutrients like $\mathrm{Fe}, \mathrm{N}$, and $\mathrm{P}$ would prevent siliceous phytoplankton from blooming even in $\mathrm{SiO}_{2}$-rich waters. Hence the inorganic mode of $\mathrm{SiO}_{2}$ precipitation proposed by Muttoni and Kent (2007).

The above views on chert and porcellanite origin can be simplified to two general scenarios - biogenic versus inorganic - to explain the ubiquitous early Paleogene silicification. The biogenic scenario, in which ${ }_{\text {bio }} \mathrm{SiO}_{2}$ accumulates on the seafloor and undergoes diagenetic alteration into cristoballite and ultimately quartz, should be viewed as more parsimonious: ${ }_{\text {bio }} \mathrm{SiO}_{2}$ is a common skeletal material that is known to easily undergo dissolution in transit through the water column, at sediment-water interface, and within the sediment (e.g., Kastner et al., 1977; Kennett, 1982; Ragueneau et al., 2000; DeMaster, 2014; Tatzel et al., 2015). Biogenic origin for the early Paleogene chert and porcellanite precursor, however, has been criticized on the grounds of the purported low productivity of the early Cenozoic oceans (Muttoni and Kent, 2007). Inorganic $\mathrm{SiO}_{2}$ precipitation requires high dissolved $\mathrm{SiO}_{2}$ concentrations in seawater (Yool and Tyrrell, 2005). Ocean waters were likely supersaturated with respect to $\mathrm{SiO}_{2}$ in the Proterozoic, but the Phanerozoic evolution of siliceous biota has caused the oceans to become $\mathrm{SiO}_{2}$-undersaturated at all depths (Maldonado et al., 1999; Conley et al., 2017). Thus, inorganic $\mathrm{SiO}_{2}$ precipitation from seawater would require a prolonged period of highly unusual oceanographic conditions during the early Cenozoic. As neither the biogenic nor the inorganic scenario has received definitive support, the source of $\mathrm{SiO}_{2}$ required for 
the formation of geographically extensive bodies of indurated siliceous sediments in the early Paleogene remains a matter of debate (e.g., Barron et al., 2015).

Previous studies suggest that the best perspective on the various aspects of $\mathrm{SiO}_{2}$ accumulation may be gained from early Paleogene sediments of the Atlantic Ocean. For much of the early Paleogene, the Atlantic was the main locus of biosiliceous sedimentation (Miskell et al., 1985; Baldauf and Barron, 1990; Penman et al., 2019), which explains why most records of early Cenozoic siliceous phytoplankton are preserved there (Barron et al., 2015). The Atlantic is also host to the majority of early Paleogene chert and porcellanite deposits reported in the deep-sea drilling literature (Muttoni and Kent, 2007; updated in Penman et al., 2019). To date, however, this coincidence has not been subject to closer scrutiny.

The aim of the present work is to test the inorganic precipitation scenario for the early Paleogene chert and porcellanite by exploring the links between $\mathrm{P}+\mathrm{E}$ biosiliceous sedimentation, and the formation of indurated siliceous deposits within the Atlantic Ocean. To this end, we present (1) a new compilation of $\mathrm{P}+\mathrm{E}$ indurated siliceous deposit occurrences in deep-sea cores taken from the Atlantic Ocean; (2) a new compilation of biogenic siliceous deposit occurrences in these same cores; and (3) new quantitative records of $\mathrm{P}+\mathrm{E}$ siliceous microfossil abundance in the western North Atlantic. Based on these data, and using published geochemical records, we provide an integrated perspective on early Paleogene siliceous sedimentation in the Atlantic Ocean.

\section{Materials and methods}

\subsection{Terminology}

Despite the well-known petrographic differences (Calvert, 1977), this study makes no distinction between chert and porcellanite, in order to correct for any inconsistencies in lithologic descriptions that may have occurred over several decades of ocean drilling that generated the data compiled herein. Chert, porcellanite, silicified limestone and silicified mudstone are here referred to collectively as 'indurated 
siliceous sediments', abbreviated as ISS. We use the term 'preserved biosiliceous sediments' (abbreviated as PBS) for all Atlantic occurrences of $\mathrm{P}+\mathrm{E}$ siliceous microfossils (radiolarians, diatoms, silicoflagellates, ebridians, synurophyte scales and siliceous dinoflagellates) reported in the deep sea literature, and those examined here. This includes not only occurrences of well-preserved assemblages, but also those in-situ occurrences that are reported as moderately or poorly preserved. Occurrences reported as reworked are not considered.

\subsection{Chronology}

All ages reported in this paper are relative to the Gradstein et al. (2012) timescale (hereafter referred to as GTS2012). Age control was established only for those Atlantic Ocean sites that recovered P+E ISS or PBS, or both. Published age models were used whenever available. These were readjusted to GTS2012 if required. For sites lacking published age data, new age models were compiled based on magnetostratigraphy, and/or foraminiferal, calcareous nannofossil, and radiolarian biostratigraphic events. Wherever available, cyclostratigraphic data were incorporated into the age models. For some intervals, especially in early DSDP holes, age control should be considered approximate. To account for this, in each ISS/PBS deposit dataset a median is plotted superimposed on a grey area that denotes the difference between sites with reliable age control and sites with approximate age control. Information on all age models used and compiled for this study can be found in Tables S1-S15 in the online Supplementary Materials.

\subsection{Atlantic P+E ISS and PBS occurrence compilation}

The compilation, designed to distinguish between those $\mathrm{P}+\mathrm{E}$ sites that recovered ISS, and those at which no such sediments were recovered, is based on a literature survey involving all DSDP, ODP and Integrated Ocean Drilling Program (IODP) sites drilled in the Atlantic Ocean. A detailed description of the compilation is presented in the online Supplementary Materials (Table S16 and Supplementary Text).

Data on siliceous microfossil occurrences (termed PBS) were tabulated from shipboard reports and post-cruise publications. Our 


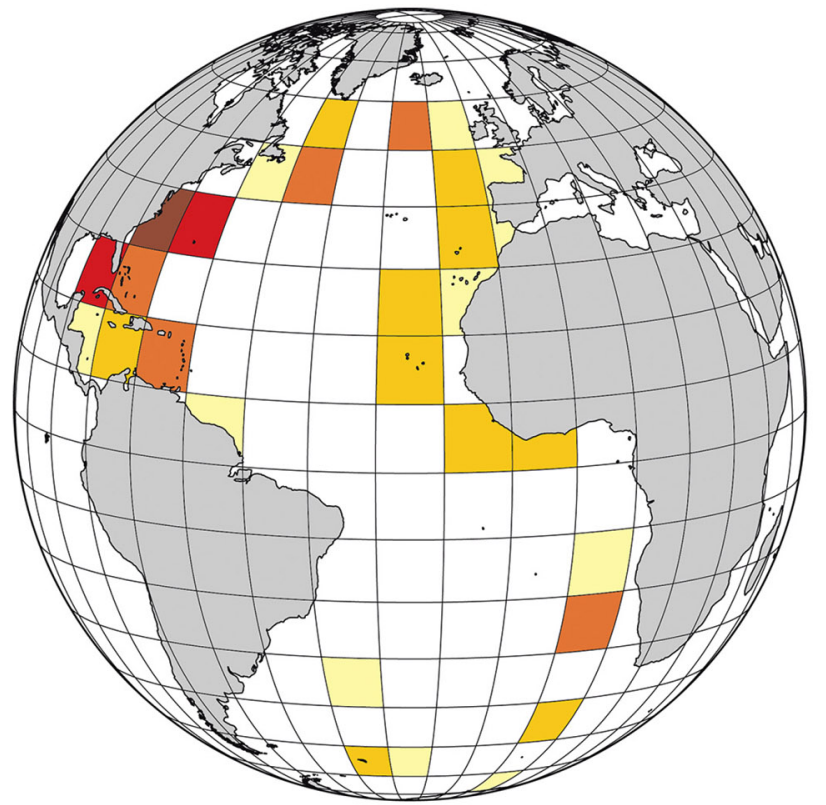

(A) Number of P+E indurated siliceous sediment occurrences

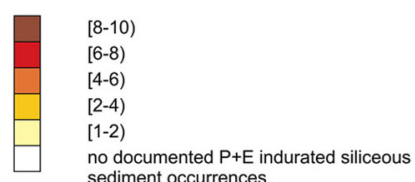

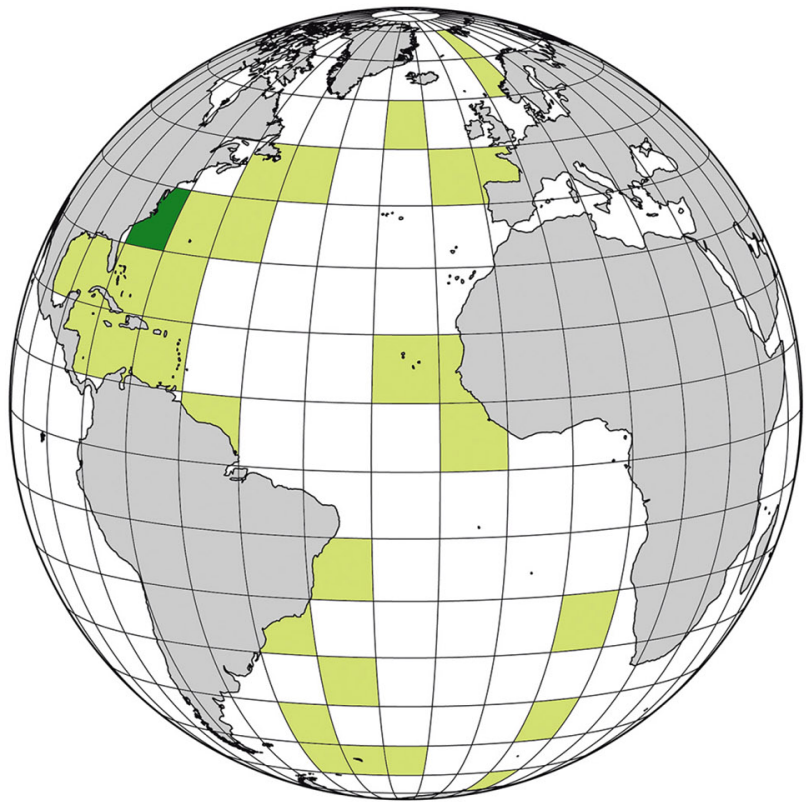

(B) Number of P+E preserved biosiliceous sediment occurrences

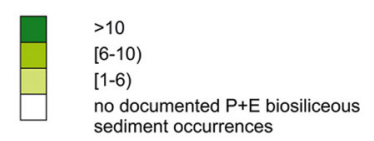

Fig. 1. Lower Paleocene through upper Eocene indurated siliceous sediment (A) versus preserved biosiliceous sediment (B) occurrences plotted on $10^{\circ}$ latitude $\times$ $10^{\circ}$ longitude grid.

compilations of ISS and PBS occurrences are presented in Figs. 1-3 in the main text and Fig. S1 and Tables S18-S19 in the online Supplementary Materials. An extended P+E Atlantic site dataset, including the relevant reference lists and information on age models, can be found in Tables S1 and S16 in the online Supplementary Materials.

All maps included in this paper were plotted on Ocean Drilling Stratigraphic Network (www.odsn.de) base maps. For the geographic distribution analysis of both ISS and PBS, sites were grouped into $10^{\circ}$ latitude $\times 10^{\circ}$ longitude bins based on their present-day geographic coordinates. A matrix of eighteen latitude bins $\left(90^{\circ} \mathrm{S}\right.$ through $\left.9 \mathrm{O}^{\circ} \mathrm{N}\right)$ $\times$ twelve longitude bins $\left(100^{\circ} \mathrm{W}\right.$ through $\left.20^{\circ} \mathrm{E}\right)$ was established to enable plotting the results in the form of a map. 


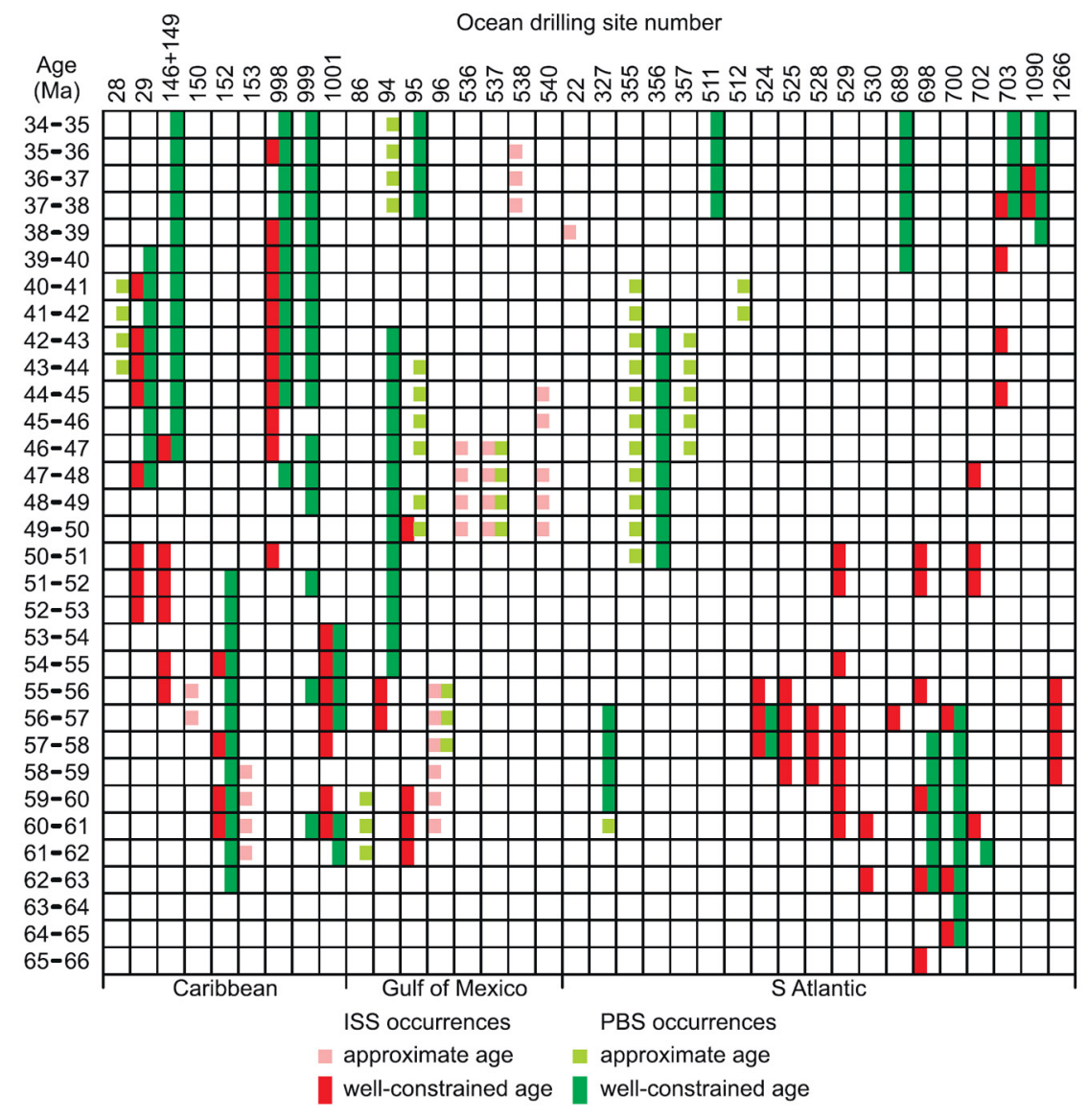

(a)

Fig. 2. Range charts showing the occurrences of lower Paleocene through upper Eocene indurated siliceous sediments (ISS) versus preserved siliceous sediments (PBS) in the Atlantic Ocean deep-sea holes in 1 million year (myr) time bins. Study sites are grouped according to the major sub-basins: Caribbean, Gulf of Mexico, and South Atlantic (a), NE Atlantic (b) and NW Atlantic (c).

\subsection{Quantitative siliceous microfossil assemblage records}

Samples from ODP Holes 1050A,C 1051A and 1053A (Blake Nose, western North Atlantic), used for siliceous microfossil examination, were freeze-dried and processed following the technique used in studies by Witkowski et al. (2012, 2014). Siliceous microfossils (diatoms, radiolarians, silicoflagellates, ebridians, chrysophyte cysts, 


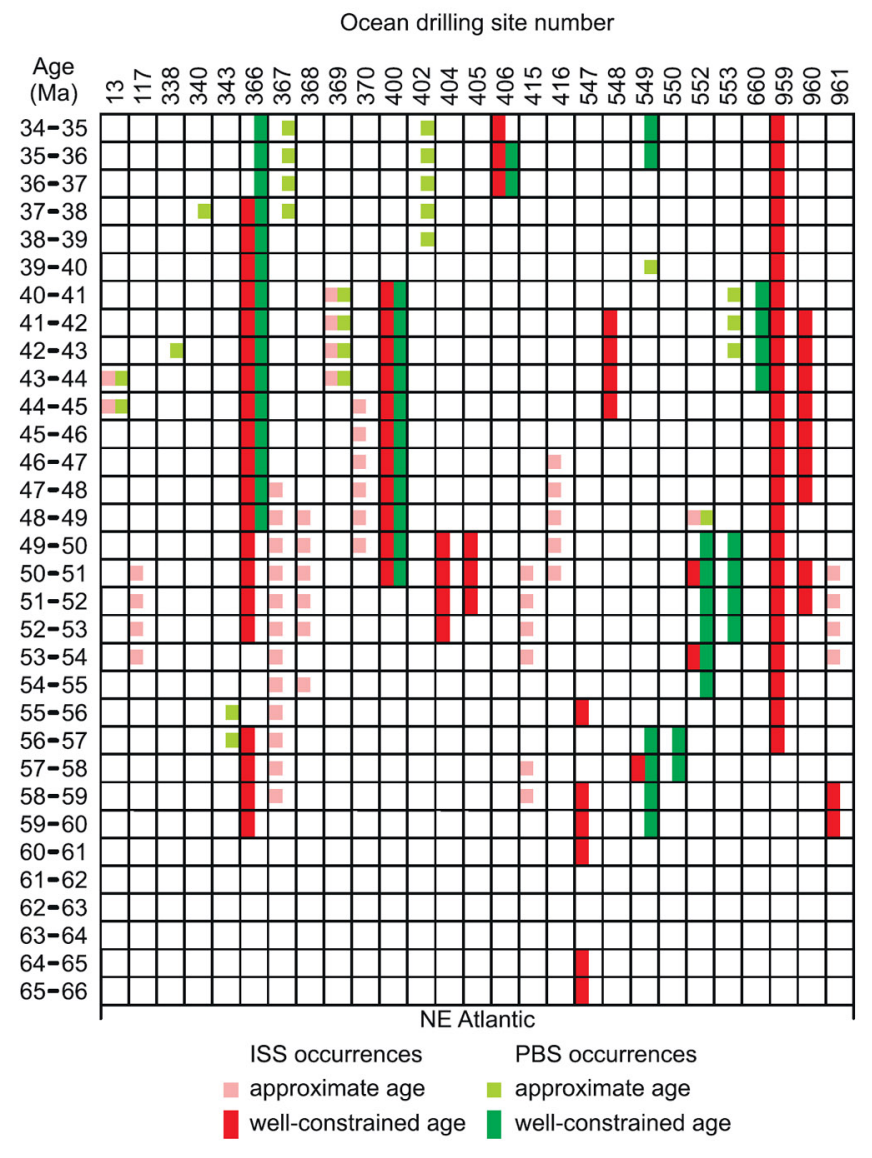

(b)

Fig. 2. $b$.

synurophyte scales and siliceous dinoflagellates) were examined and counted using light microscopy. Absolute abundances were established following the method outlined in Witkowski et al. (2012). Due to the large amount of micropaleontological data collected, detailed taxonomic accounts will be published separately. Here, we present only the data relevant to this study (see Table S17 in the online Supplementary Materials). 


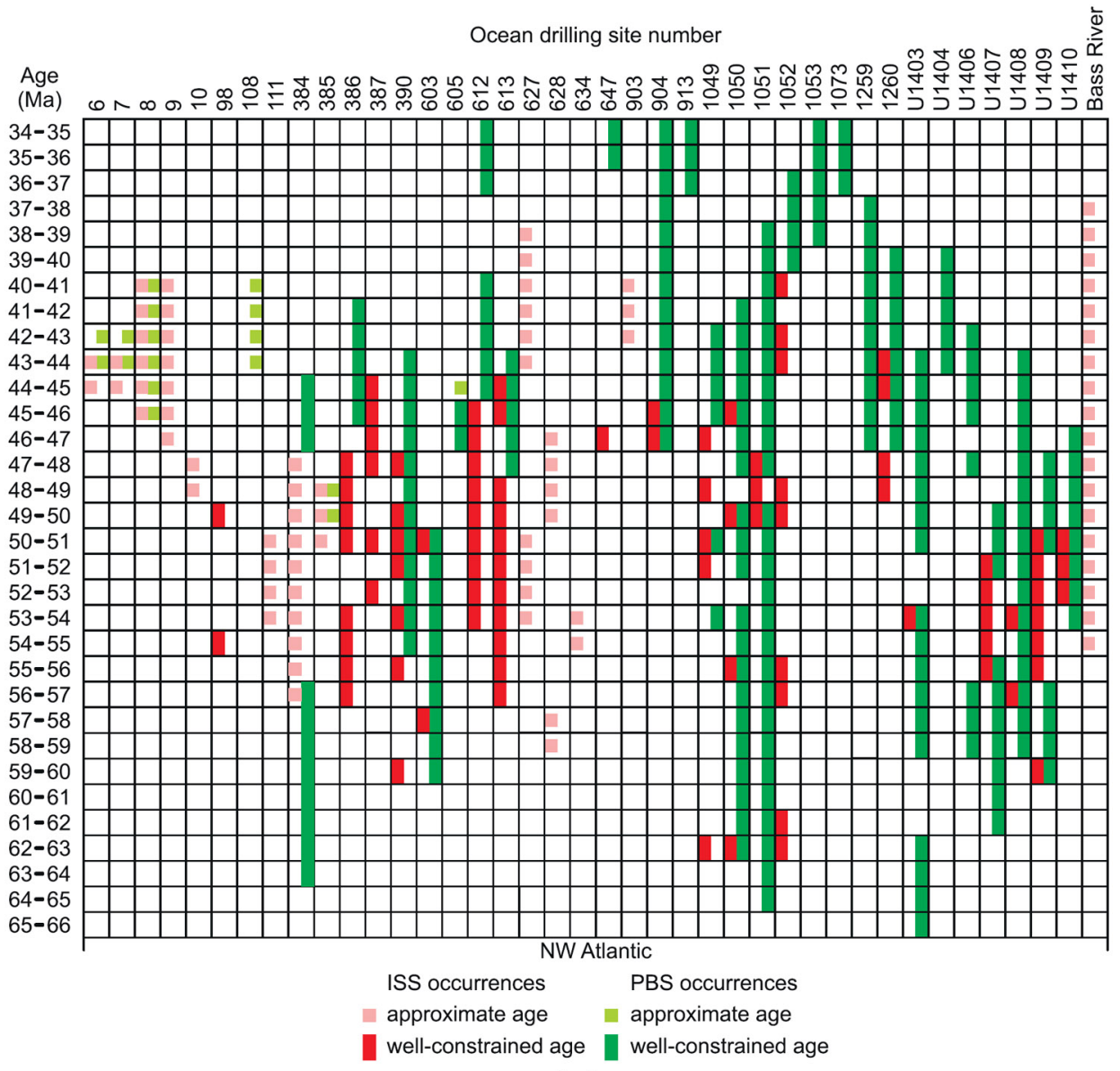

(c)

Fig. 2. c.

Fig. 3. Secular distribution of lower Paleocene through upper Eocene indurated siliceous sediment (ISS) (A) and preserved biosiliceous sediment (PBS) (B) occurrences in the Atlantic Ocean plotted versus published silicate weathering flux (SWF) curve (C) and benthic foraminiferal carbon and oxygen stable isotope records (D). Grey areas in ISS and PBS plots denote the difference between the number of sites with reliable age control and approximate age control in each 1-myr time bin. Schematic representation of climatic trends through the early Paleogene is consistent with Cramwinckel et al. (2018). SWF data from Caves et al. (2016). $\delta^{13} \mathrm{C}$ and $\delta^{18} \mathrm{O}$ data from Cramer et al. (2009; readjusted to GTS2012). Approximate ranges of onshore diatom-bearing stratigraphic units provided in panel B are discussed in text. 


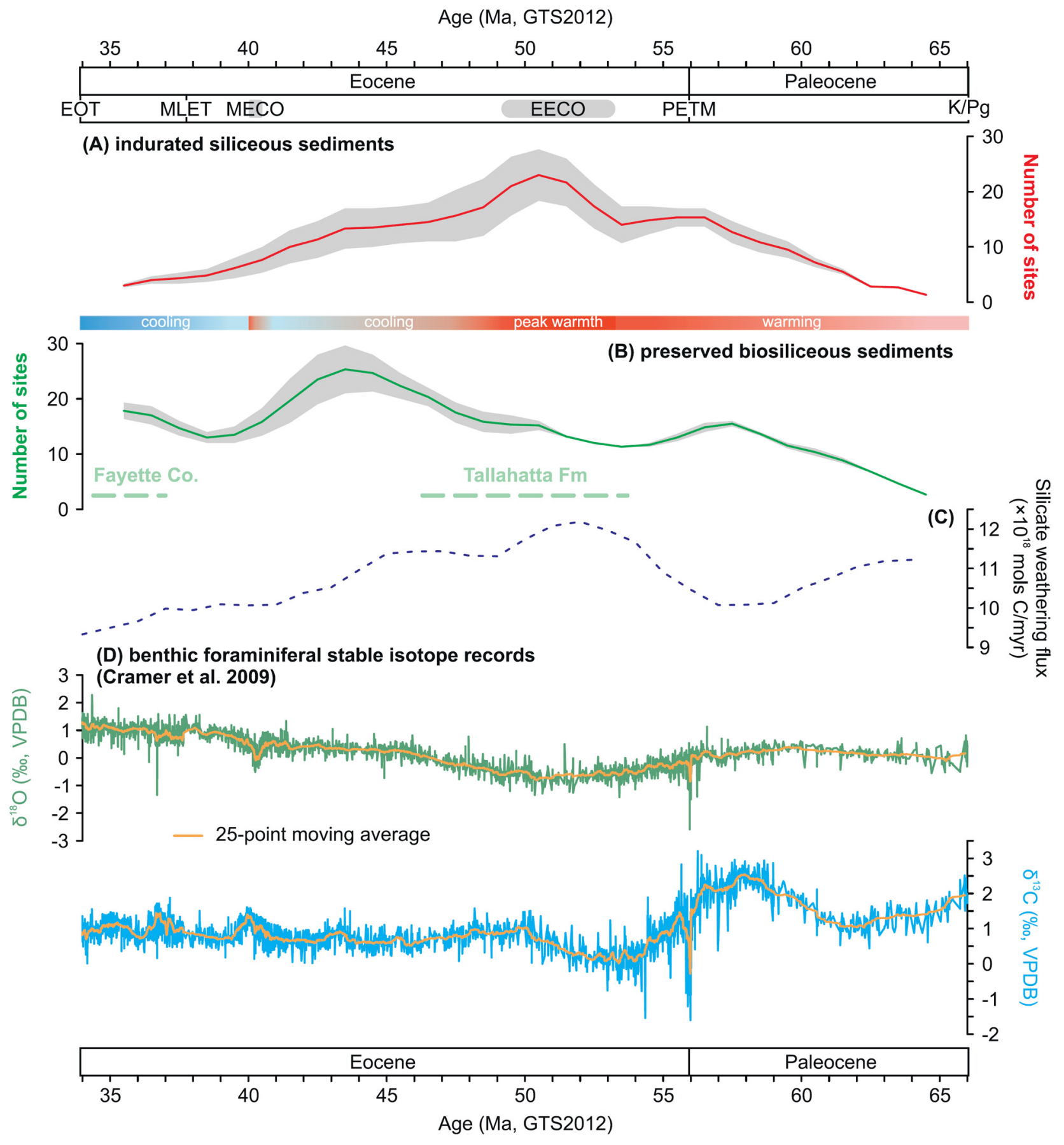




\section{Spatial and temporal distribution of P+E Atlantic siliceous sediments}

\subsection{Geographic distribution}

\subsubsection{Indurated siliceous sediments}

Out of 190 sites in the Atlantic Ocean that recovered $\mathrm{P}+\mathrm{E}$ intervals, occurrences of ISS are documented at 83 sites (Fig. 2; Fig. S1; Table S1). These are confined to between $\sim 65^{\circ} \mathrm{S}$ and $\sim 57^{\circ} \mathrm{N}$ (Fig. $1 \mathrm{~A}$; Fig. S1A). In the North Atlantic, P+E ISS occur in each $10^{\circ}$ latitude $\times$ $10^{\circ}$ longitude bin adjacent to the South American and North American coast, including the Caribbean and the Gulf of Mexico (Fig. 1A). Similarly, P+E ISS occur within each bin adjacent to the coasts of West Africa and Europe from the western Gulf of Guinea in the south to Rockall Plateau in the north (Fig. 1A; Fig. S1A). In the South Atlantic, ISS occurrences are patchy, and mostly associated with topographic highs, including the São Paulo Plateau (Site 356), Rio Grande Rise (Site 357), Walvis Ridge (Sites 525-529, 1266), Northeast Georgia Rise (Site 698), Islas Orcadas Rise (Site 702), Agulhas Ridge (Site 1090), and Maud Rise (Site 689) (Fig. 1A; Fig. S1). Wherever present, ISS occurrences average 2.8 per $10^{\circ}$ latitude $\times 10^{\circ}$ longitude bin. Consistent with previous studies (Muttoni and Kent, 2007), the highest number of ISS occurrences is reported from a crescent-shaped area encompassing the Caribbean, Gulf of Mexico, and the Western North Atlantic (Fig. 1A; Fig. S1A), between $10^{\circ}$ and $40^{\circ} \mathrm{N}$, and between $60^{\circ}$ and $90^{\circ} \mathrm{W}$ (Figs. S1A; S2A). Peak ISS frequency is observed along the eastern North American seaboard (Fig. 1A; Fig. S1), including Hatteras Abyssal Plain (Site 603), New Jersey continental rise and slope (Sites 605, 612, 613, 903-904) and Blake Nose (Sites 1049-1052) areas (Fig. 1A; Fig. S1).

Although the bin resolution gives a rather coarse representation of ISS distribution, the documented occurrences of $\mathrm{P}+\mathrm{E}$ ISS are confined to proximal sites. No ISS are reported from $\mathrm{P}+\mathrm{E}$ sites located closer to the axial zone of the Atlantic Ocean (Fig. 1A). 


\subsubsection{Preserved biosiliceous sediments}

$\mathrm{P}+\mathrm{E}$ PBS are found at 70 sites in the Atlantic Ocean (Fig. 2; Fig. S1; Table S1). These are confined to between $\sim 70^{\circ} \mathrm{S}$ and $\sim 80^{\circ} \mathrm{N}$ (Fig. 1B). As previously observed for ISS occurrences, Atlantic sites with $\mathrm{P}+\mathrm{E}$ PBS occur in settings proximal to the coasts of all continents, and are absent from the axial part of the Atlantic Ocean (Fig. 1B). In the North Atlantic, $\mathrm{P}+\mathrm{E}$ PBS are found in each $10^{\circ}$ latitude $\times 10^{\circ}$ longitude bin adjacent to the South American and North American coasts between the equator and $50^{\circ} \mathrm{N}$, including the Caribbean and the Gulf of Mexico (Fig. 1B). Along the eastern margin of the Atlantic Ocean, there are two zones of $\mathrm{P}+\mathrm{E}$ PBS occurrences. The northern zone, between $40^{\circ} \mathrm{N}$ and $80^{\circ} \mathrm{N}$, includes Vøring Plateau (Sites 338, 340, 343), East Greenland Basin (Site 913), Bay of Biscay (Sites 400, 402), Rockall Plateau margin (Site 406), Pendragon Escarpment (Site 549), and Edoras Basin (Sites 552, 553). The southern zone is in the equatorial and subtropical Atlantic between $\mathrm{O}^{\circ}$ and $20^{\circ} \mathrm{N}$ (Fig. 1B) and includes sites located on Sierra Leone Rise (Sites 13, 366), and within Cape Verde Basin (Site 367) and Kane Gap (Site 660). In the South Atlantic, a belt of P+E PBS extends along the South American coast from $10^{\circ} \mathrm{S}$ to $70^{\circ} \mathrm{S}$, continuing as a prominent longitudinal belt between $60^{\circ} \mathrm{S}$ and $70^{\circ} \mathrm{S}$ (Fig. 1B). The latter encompasses Sites 327, 511, 512, 698, 700, and 702. P+E PBS in the Southeast Atlantic are confined to few sites, again associated with basement elevations, including Maud Rise (Site 689), Meteor Rise (Site 703), and Agulhas Rise (Site 1090) (Fig. 1B). Overall, PBS occurrences average 2.0 per $10^{\circ}$ latitude $\times 10^{\circ}$ longitude bin, wherever present. The highest number of PBS occurrences is reported from the western North Atlantic between $30^{\circ}$ and $40^{\circ} \mathrm{N}$, and $70-80^{\circ} \mathrm{W}$, i.e., along the ISS-rich North American margin (Fig. 1A vs 1B).

Thus, Atlantic Ocean P+E ISS and PBS distribution patterns are highly coherent. These sediment types co-occur at 46 of the investigated sites (Fig. 2; Table S1), which strongly suggests a causal link. More importantly, however, the proximal distribution of siliceous sediments of both types points to the largely overlooked significance of marginal settings in early Paleogene ${ }_{\text {bio }} \mathrm{SiO}_{2}$ production and burial. 


\subsection{Secular distribution}

\subsubsection{Indurated siliceous sediments}

Although we report ISS occurrences within P+E intervals from 83 sites, three sites $(12,138$, and 140) are excluded from the following discussion due to lack of age control. The temporal distribution of $\mathrm{P}+\mathrm{E}$ ISS in the Atlantic Ocean shows a sustained rise from the early Paleocene (Fig. 3A). A plateau is reached between 56 and $57 \mathrm{Ma}$, and persists across the Paleocene-Eocene boundary. A steep rise in ISS occurrences commences between 54 and $53 \mathrm{Ma}$. The highest number of ISS deposits is observed in the time bin between 51 and $50 \mathrm{Ma}$, i.e., within the latter half of Early Eocene Climatic Optimum (EECO) (Fig. 3A). This result is consistent with the global trend reported by Muttoni and Kent (2007). A steady decline in the number of P+E ISS deposits is observed after 50 Ma. Except for a plateau between 45 and $44 \mathrm{Ma}$, this trend persists to the late Eocene (Fig. 3A). Regional trends in ISS distribution through time are briefly discussed in the Supplementary Text (see also Fig. S2).

As previously discussed by Muttoni and Kent (2007), the secular distribution of $\mathrm{P}+\mathrm{E}$ ISS occurrences appears inversely correlated with long-term trends in benthic foraminiferal $\delta^{18} \mathrm{O}$ (Cramer et al., 2009) (Figs. 3A, D; 4A). The trends in ISS occurrences and $\delta^{18} \mathrm{O}$ are in reasonably good agreement especially for the Eocene (Figs. 3A; 4A). Given the absence of extensive polar ice sheets generally assumed for the early Paleogene (Edgar et al., 2007; Anagnostou et al., 2016), this suggests a strong thermal control on the ISS formation in the Atlantic Ocean. However, considering the consistent geographic distribution of ISS and PBS discussed above, the good agreement between $\delta^{18} \mathrm{O}$ and ISS occurrences through time also suggests enhanced ${ }_{\text {bio }} \mathrm{SiO}_{2}$ dissolution by warm bottom waters bathing the continental margins (e.g., DeMaster, 2014; Frings, 2017; Wade et al., 2020). Correlation between benthic foraminiferal $\delta^{13} \mathrm{C}$ (Cramer et al., 2009) and secular distribution of $\mathrm{P}+\mathrm{E}$ ISS occurrences is weak (Fig. 4C), implying no apparent links between the long-term carbon cycle trends and ${ }_{\text {bio }} \mathrm{SiO}_{2}$ diagenesis in the Atlantic Ocean through the early Paleogene. A comparison of temporal trends in ISS distribution to the silicate weathering flux (SWF) modelled by Caves et al. (2016) displays a contrasting 
pattern, with a moderately strong inverse correlation for the Paleocene and a moderately strong positive correlation for the Eocene (Fig. $4 \mathrm{E})$. Further, the peak in ISS occurrences lags peak SWF by 1-2 million years (myrs) (Fig. 3C). We discuss this discrepancy in more detail in Section 6.1.

(A) ISS occurrences per $1 \mathrm{myr}$ bin

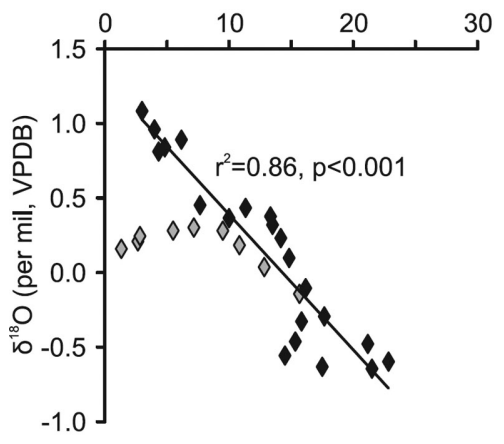

(C) ISS occurrences per 1 myr bin

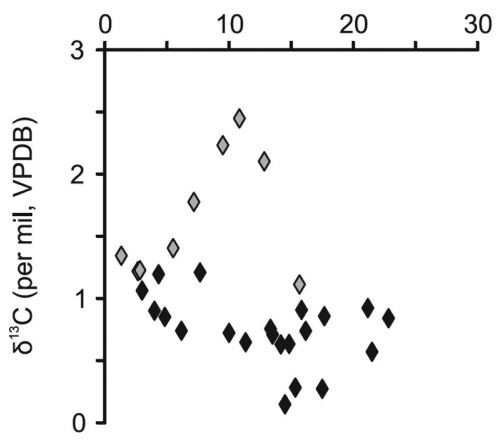

(E) ISS occurrences per 1 myr bin

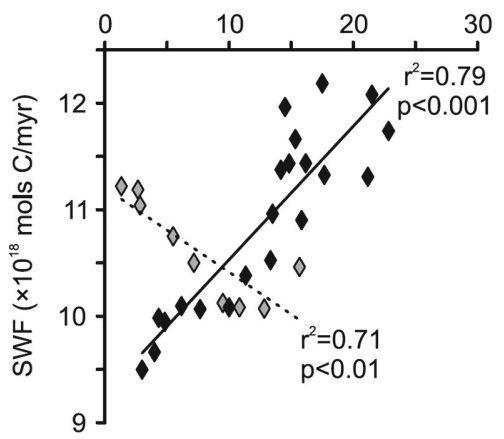

(B) PBS occurrences per 1 myr bin

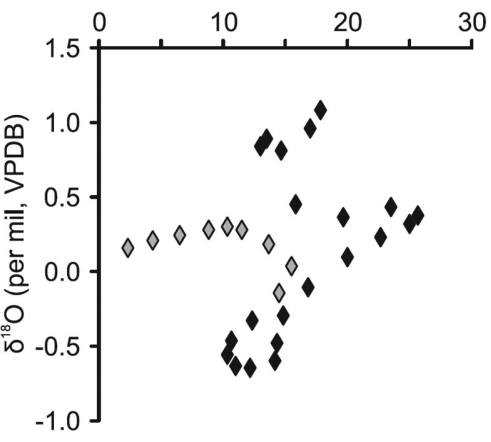

(D) PBS occurrences per 1 myr bin

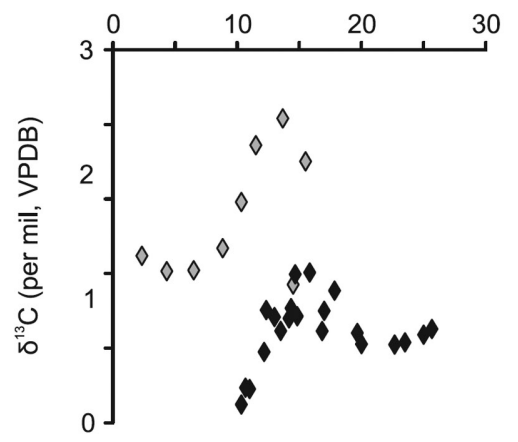

(F) PBS occurrences per 1 myr bin

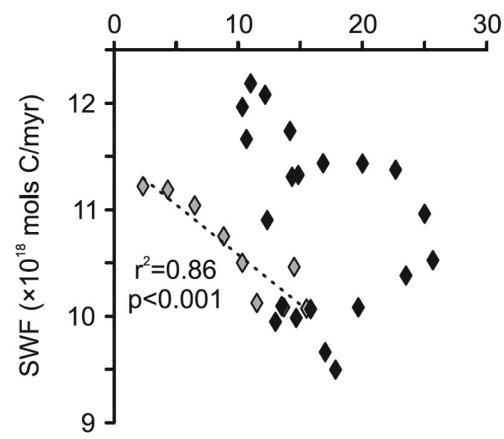

Fig. 4. Regression plots for indurated siliceous sediments (ISS) and preserved biosiliceous sediments (PBS) against published $\delta^{18} \mathrm{O}(\mathrm{A}-\mathrm{B}), \delta^{13} \mathrm{C}(\mathrm{C}-\mathrm{D})$ from Cramer et al. (2009), and against silicate weathering flux (SWF) ( $E-F$ ) from Caves et al. (2016). $\mathrm{R}^{2}$ and $p$ values are given only for statistically significant correlations. 


\subsubsection{Preserved biosiliceous sediments}

The number of Atlantic Ocean PBS deposits shows a steady increase from the early Paleocene until a minor peak is reached between 58 and $57 \mathrm{Ma}$ (Fig. 3B). Fewer PBS occurrences are recorded between $\sim 57$ and $53 \mathrm{Ma}$, when a prolonged increasing trend in the number of PBS deposits is initiated (Fig. 3B). This increase is interrupted only by a transient plateau at $\sim 50 \mathrm{Ma}$, followed by an interval of steep rise that culminates between 44 and $43 \mathrm{Ma}$ (Fig. 3B). Following this, the number of PBS deposits decreases. A minor rise is observed only in the late Eocene (Fig. 3B). Thus, on a basin scale, the secular distribution of PBS shows a considerably different pattern than that observed for ISS (Fig. 3A vs B). The most notable difference is the fact that the interval of peak ISS occurrences coincides with an interval of generally low PBS frequency. Regional trends in PBS distribution through time are briefly discussed in the Supplementary Text (see also Fig. S2).

Muttoni and Kent (2007) also observed a generally inverse relationship between the frequency of ISS and siliceous microfossil occurrences through time. They argued that the paucity of diatom and radiolarian occurrences in early Paleogene deep-sea sediments suggested that abundant chert occurrences through the EECO required an inorganic mode of $\mathrm{SiO}_{2}$ precipitation. Unlike Muttoni and Kent (2007), we interpret the overall inverse relationship between ISS and PBS occurrences through time to indicate ISS formation at the expense of PBS. This is consistent with the view that opal-A is temporally unstable and, under favorable pressure and temperature conditions and on long timescales, undergoes diagenetic alteration to opal-CT and subsequently quartz (Hesse, 1983; Hein et al., 1990; DeMaster, 2014; Frings, 2017).

The comparison between $\mathrm{P}+\mathrm{E}$ PBS secular distribution and published stable isotope records is less straightforward than for ISS (Fig. 3B, D). Linear correlations are either weak or inconclusive (Fig. 4B, D). Further, through the Paleocene, PBS occurrences are strongly inversely correlated to the SWF model of Caves et al. (2016) (Fig. 3C). For the Eocene, there is a weak negative SWF-PBS correlation (Fig. $4 \mathrm{~F}$ ). We interpret these contrasting relationships to support the diagenetic origin of the $\mathrm{P}+\mathrm{E}$ ISS: the correlations are inconclusive as the original pool of the Atlantic Ocean PBS is depleted due to diagenetic ISS formation 


\subsection{ISS and PBS co-occurrences vs wt $\%_{b i o} \mathrm{SiO}_{2}$ records and linear sedimentation rates}

ISS co-occur with PBS at various levels at 46 sites, out of 70 PBS and 83 ISS sites considered here (Fig. 2). In order to gain a closer insight into these co-occurrences, we examine several multi-myr-long weight per cent (hereafter wt\%) ${ }_{\text {bio }} \mathrm{SiO}_{2}$ records from western North Atlantic sites that recovered both sediment types. $\mathrm{Wt} \%{ }_{\text {bio }} \mathrm{SiO}^{2}$ and linear sedimentation rate (LSR) data are from Witkowski et al. (2020b).

Site U1403 (J-Anomaly Ridge; Table S16) recovered discrete ISS horizons within $\mathrm{a}_{\text {bio }} \mathrm{SiO}_{2}$-rich interval that coincides with an interval of low LSRs (Fig. 5). Site 384, also located at J-Anomaly Ridge (Table S16), represents an extreme case of ISS coinciding with a prolonged period of deep-sea erosion at the Early-Middle Eocene transiton. The two chert layers observed at the base of Core 384-5R occur within $\mathrm{a}_{\text {bio }} \mathrm{SiO}_{2}$-rich interval that includes up to three tightly-spaced stratigraphic gaps (Aubry, 1995). Sediment-water interface exposure of bio$\mathrm{SiO}_{2}$ to highly $\mathrm{SiO}_{2}$-undersaturated ocean waters is a well-known factor in $\mathrm{SiO}_{2}$ dissolution (DeMaster, 2014; Frings, 2017). Seafloor ${ }_{\text {bio }} \mathrm{SiO}_{2}$ dissolution leads to pore water enrichment in silicic acid. Whereas part of the pore-water dissolved $\mathrm{SiO}_{2}$ content is returned to the bottom waters as benthic flux (Van Cappellen et al., 2002), the remainder undergoes diagenetic alteration to opal-CT and, ultimately, quartz (Kastner et al., 1977). In today's oceans, both seafloor ${ }_{\text {bio }} \mathrm{SiO}_{2}$ dissolution rate and benthic flux kinetics are dependent on a number of factors, including temperature, host lithology, and particulate matter supply (DeMaster, 2014). Given that in the early Paleogene water column temperature gradients likely differed from those of the Neogene and the Recent (with water column dissolution rate exceeding seafloor dissolution rate), the relationship between water-column and seafloor ${ }_{\text {bio }} \mathrm{SiO}_{2}$ dissolution rates may have differed from today. Also, the benthic flux efficiency may have differed from today's, given the considerably warmer bottom water temperatures indicated by benthic foraminiferal $\delta^{18} \mathrm{O}$ records (Zachos et al., 2001; Cramer et al., 2009).

At Site 1050 (Blake Nose), the siliceous microfossil-rich P+E section is unusually expanded and includes seven ISS levels associated with moderate and high ${ }_{\text {bio }} \mathrm{SiO}_{2}$ concentrations. Two ISS levels (at $\sim 62.40-$ 62.43 Ma in Hole 1050C) fall within an interval of high LSRs (Fig. 5). 
Age (Ma, GTS2012)
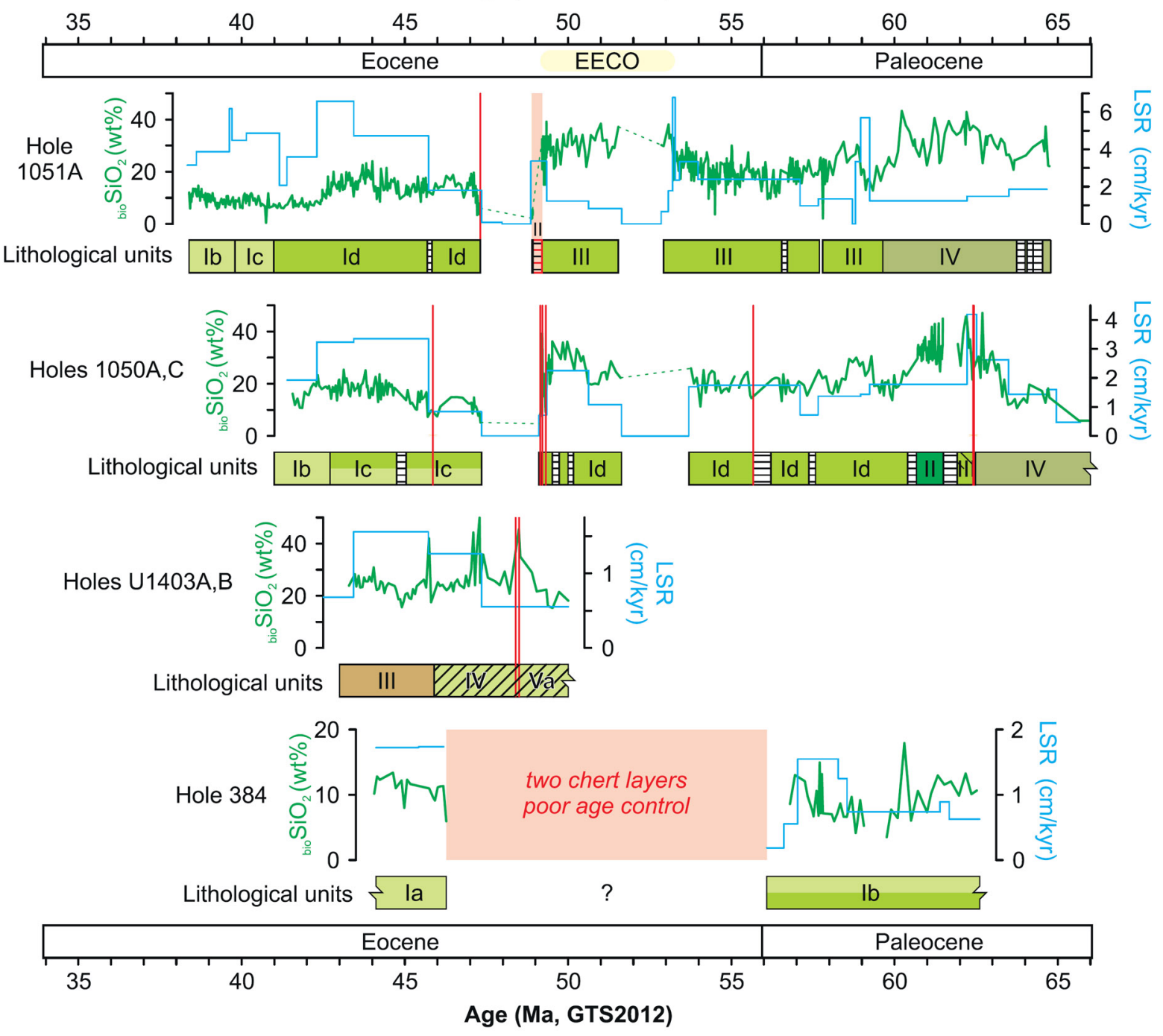
clay/claystone
calcareous chalk $\square$ clayey intervals
$\square$ chert
radiolarian/diatom clay
calcareous ooze
recovery gap
porcellanite
diatomite

Fig. 5. ${ }_{\mathrm{Bio}} \mathrm{SiO}_{2}$ concentrations (weight per cent, wt\%) plotted against linear sedimentation rates (LSR), generalized lithology, and indurated siliceous sediment (ISS) occurrences at selected western North Atlantic sites through the early Paleocene to late Eocene period. Roman numerals refer to lithological units distinguished in the relevant site reports (see Table S16 in the online Supplementary Materials for a complete list of references). ${ }_{\mathrm{Bio}} \mathrm{SiO}_{2}$ concentrations and LSR data from Witkowski et al. (202ob). 
These could represent a different mode of silicification, i.e., resulting from elevated pressure and temperature conditions due to rapid burial (see Riech and von Rad, 1979). The remaining ISS occurrences at Site 1050 are correlative with lower LSRs, lending further support to the importance of ${ }_{\text {bio }} \mathrm{SiO}_{2}$-rich sediment exposure to $\mathrm{SiO}_{2}$-undersaturated bottom waters in the formation of the widespread Atlantic P+E ISS.

\subsection{Recapitulation}

Three major conclusions can be drawn from the above review: 1) both ISS and PBS occur mostly in sites that are proximal to continental margins, and on basement elevations; Atlantic P+E sites located further offshore recover other sediment types, lacking ISS and PBS (Fig. 1, Fig. S1); 2) ISS and PBS occurrences show dissimilar distributions through time, with an overall increasing trend for PBS, and a prominent peak in ISS occurrences between 51 and 50 Ma. ISS and PBS co-occur at 46 sites, often over long time intervals (Fig. 2); 3) in most cases, ISS form discrete horizons within PBS intervals; these horizons often correlate with elevated ${ }_{\text {bio }} \mathrm{SiO}_{2}$ levels and low LSRs (Fig. 5). These observations strongly suggest that ISS in the Atlantic Ocean

are a product of diagenesis of ${ }_{\text {bio }} \mathrm{SiO}_{2}{ }^{-}$rich precursors. In order to set the above observations in the context of paleoproductivity, we proceed to discuss variations in siliceous microfossil assemblages as revealed by ODP sites 1050, 1051 and 1053 (Table S16). These sites are located on the Blake Nose, i.e., immediately adjacent to the area characterized by the highest frequencies of P-E ISS and PBS (Fig. 1A-B). Further, the Blake Nose sites are unique on a global scale in that they represent the most continuous available record of biosiliceous sedimentation through the early Paleogene from a single locality (Fig. 2) (Witkowski et al., 2020a).

\section{Lower Paleocene through upper Eocene biosiliceous sedimen- tation at Blake Nose}

Siliceous microfossils are found throughout the studied successions at Blake Nose sites, except for several narrow dissolution intervals (grey bands in Fig. 6), in which siliceous sponge spicules and 


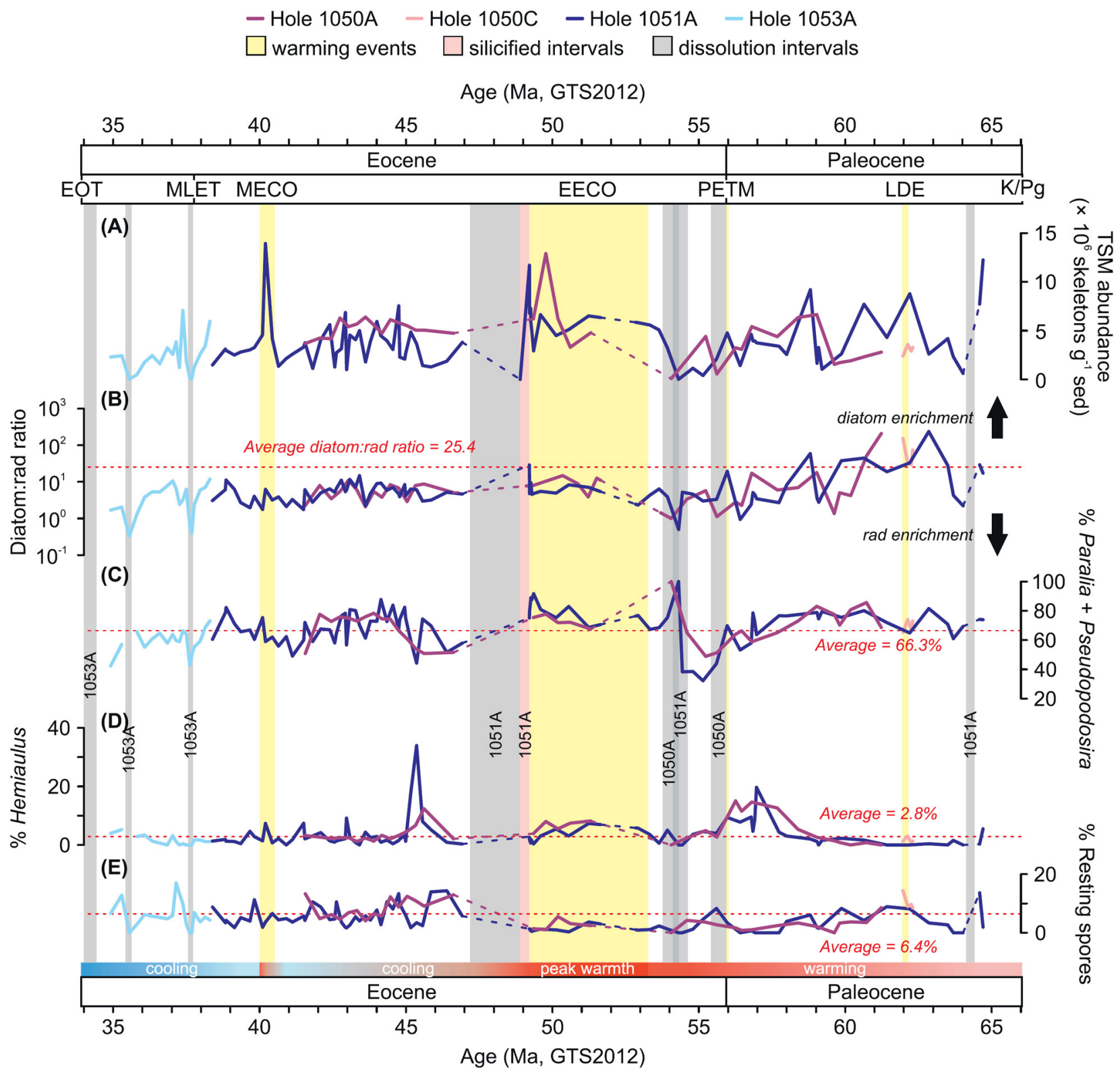

Fig. 6. Siliceous microfossil assemblage records through the early Paleocene through late Eocene period at ODP Holes 1050A,C, 1051A, and 1053A. (A) Variations in Total Siliceous Microfossil (TSM) abundance. (B) Diatom:radiolarian ratios. (C) Relative abundance of neritic diatoms, based on Paralia spp. and Pseudopodosira spp. (D) Relative abundance of pelagic diatoms, exemplified by Hemiaulus spp. (E) Relative abundance of diatom resting spores. Schematic representation of climatic trends through the early Paleogene is consistent with Cramwinckel et al. (2018). 
poorly preserved radiolarians are observed in the absence of siliceous phytoplankton. At each study site, diatoms represent the dominant group of siliceous microfossils, making up on average $\sim 80.6 \%$ of the assemblage by number of individuals. Intervals of the highest total siliceous microfossil abundance (hereafter referred to as TSM, following Witkowski et al., 2012) appear to coincide with major periods of climatic and biotic turnovers: the final phases of the EECO (Luciani et al., 2016; Westerhold et al., 2018), the peak of the Middle Eocene Climatic Optimum (MECO) (Bohaty et al., 20o9; Witkowski et al., 2014; Cramwinckel et al., 2019), and shortly after the Middle-Late Eocene Turnover event (MLET) (Kamikuri and Wade, 2012). Interpreting the $\sim 64.7$ Ma peak in TSM abundance is problematic due to the missing earliest Paleocene record (Fig. 6A). Sites that do preserve earliest Paleocene siliceous plankton, however, suggest enhanced biosiliceous sedimentation in the period after the $\mathrm{K} /$ Pg event (Hollis et al., 1995).

The most notable feature of siliceous microfossil assemblages at the study sites are the high diatom:radiolarian (D:R) ratios, which are considered a measure of the proportion of ${ }_{\text {bio }} \mathrm{SiO}_{2}$ produced by diatoms versus radiolarians (Hollis et al., 1995; Renaudie et al., 2018) (Fig. 6B). D:R ratios $>200$ are observed during the latest early Paleocene between $\sim 61.2$ and $62.8 \mathrm{Ma}$, an interval encompassing the Latest Danian Event and its aftermath (LDE; Dinarès-Turell et al., 2012) (Fig. 6B). Following this, a steady, long-term decline is initiated, probably reflecting the increasingly open marine depositional setting. The average $D: R$ ratio value is $\sim 25.5$, and the rapid drops in the D:R ratio coincide with diatom dissolution intervals (Fig. 6B). Thus, the relative enrichment in radiolarians over these intervals is more likely due to nonpreservation of diatoms rather than any kind of rapid environmental change.

The most abundant diatoms at the Blake Nose sites are the neritic genera Paralia Heiberg and Pseudopodosira Jousé (Fig. 6C). Together, these two genera make up on average $66.3 \%$ of the diatom assemblage throughout the study interval (Fig. 6C). Except for the dissolution intervals, the Paralia+Pseudopodosira percentages generally oscillate around the average level. We interpret this unusually high proportion of neritic taxa in the open marine setting to signify persistent, high diatom production on the North American margin 
combined with an efficient means of offshore export, as observed today in the South Atlantic Bight region adjacent to the Blake Plateau (Lee et al., 1991).

The pelagic genus Hemiaulus Heiberg has an average abundance of $\sim 2.8 \%$ (Fig. 6D). There are two intervals of elevated Hemiaulus percentages: from $\sim 59$ through $\sim 56 \mathrm{Ma}$, and from $\sim 47$ through $45 \mathrm{Ma}$ (Fig. 7D). The relative abundance of Hemiaulus is above average also from $\sim 53.5$ through $\sim 50 \mathrm{Ma}$, which is bracketed by intervals of dissolution and silicification (Fig. 6D). It is therefore likely that the whole period between $~ 59$ and 45 Ma was characterized by elevated abundances of hemiauloids, but the record was subsequently truncated by diagenetic processes. Modern hemiauloids are adapted to nutrientpoor conditions (Kemp and Villareal, 2018), and in paleoenvironmental reconstructions they are often considered as stratified water column indicators. We interpret elevated hemiauloid percentages in the late Paleocene through the EECO, and in the early phases of the middle Eocene cooling, to signify a long-term oligotrophic regime in the western North Atlantic surface waters (Fig. 6D).

The average abundance of diatom resting spores in the whole study interval is $\sim 6.4 \%$ (Fig. $6 \mathrm{E}$ ); generally, resting spore percentages appear to be inversely correlated to hemiauloid percentages (Fig. 6D vs E). Through the Paleocene and early Eocene, the resting spore percentage is generally below average. From $\sim 47 \mathrm{Ma}$, however, resting spore abundance generally increases (Fig. 6E). We interpret this trend to reflect increased seasonality, with successive periods of nutrient enrichment and depletion. This is consistent with invigorated vertical mixing of the western North Atlantic waters from the onset of the long-term cooling trend shortly after the termination of the EECO (Hohbein et al., 2012; Vahlenkamp et al., 2018).

Variations in the Blake Nose siliceous microfossil assemblages suggest (1) a largely oligotrophic setting in the pelagic zone of the Western North Atlantic Ocean for the Paleocene through early Eocene period, and a post-EECO trend toward higher nutrient availability; (2) persistent high diatom production along the North American margin, with an efficient means of lateral transport of neritic diatoms into the open ocean zone by surface currents. We propose that despite the lownutrient regime prevailing in the Western North Atlantic Ocean for a prolonged period in the Paleocene and early Eocene, these neritic 
diatoms represent the source of ${ }_{\text {bio }} \mathrm{SiO}_{2}$ that ultimately became dissolved and reprecipitated as ISS. This helps explain why the Western North Atlantic hosts the largest volumes of ISS, but requires an interpretation in light of ocean circulation changes, which follows below.

\section{Shifts in $\mathrm{P}+\mathrm{E}$ Atlantic $\mathrm{SiO}_{2}$ accumulation loci}

As a final aspect in our interpretation of $\mathrm{P}+\mathrm{E}$ siliceous sedimentation in the Atlantic Ocean, we use the wealth of data accumulated in this study to plot paleogeographic maps documenting how the loci of siliceous sediment accumulation shifted through time (Fig. 7). Most importantly, the maps indicate the areas of most persistent siliceous sediment accumulation through the $\mathrm{P}+\mathrm{E}$ time interval, but they also provide an integrated perspective on the links between biogenic siliceous sedimentation and the formation of indurated siliceous deposits (Fig. 7). We include four time slices in the main text, but a complete set of paleogeographic maps is provided in the online Supplementary Materials (Fig. S3).

The earliest, most persistent and most geographically extensive zone of $\mathrm{P}+\mathrm{E}_{\text {bio }} \mathrm{SiO}_{2}$ accumulation in the Atlantic Ocean is found in the western North Atlantic (Fig. S3). It was established at $65 \mathrm{Ma}$, and initially represented by mid-latitude sites (Sites 1051 and U1403). By the late Paleocene, however, the belt stretched along the entire eastern coast of North America (Fig. 7A). It reached its maximum geographic range between 51 and $50 \mathrm{Ma}$. By that time it extended from the Colombian Basin in the SW (Site 29) to the Hatton-Rockall Basin in the NE (Site 117) (Fig. 7B). The rapid expansion of this zone suggests an early flow of a proto-Gulf Stream (Gradstein and Sheridan, 1983; Wade and Kroon, 2002) distributing nutrients along the North American margin and sustaining ${ }_{b i o} \mathrm{SiO}_{2}$ production in the marginal part of the NW Altantic. As the North Atlantic broadened, the northern ${ }_{\text {bio }} \mathrm{SiO} 2$ accumulation zone diminished, and eventually split into a NW and NE sector (Fig. S3) following $49 \mathrm{Ma}$. The NE P+E ${ }_{b i o} \mathrm{SiO}_{2}$ accumulation zone is represented by few sites characterized by a discontinuous record (e.g., Holes 340; 400A; 406; 549; see Table S1). The NW zone, however, persisted until the late Eocene, albeit with a diminished geographic extent (Fig. 7C-D). 
(A) 56-57 Ma, late Paleocene

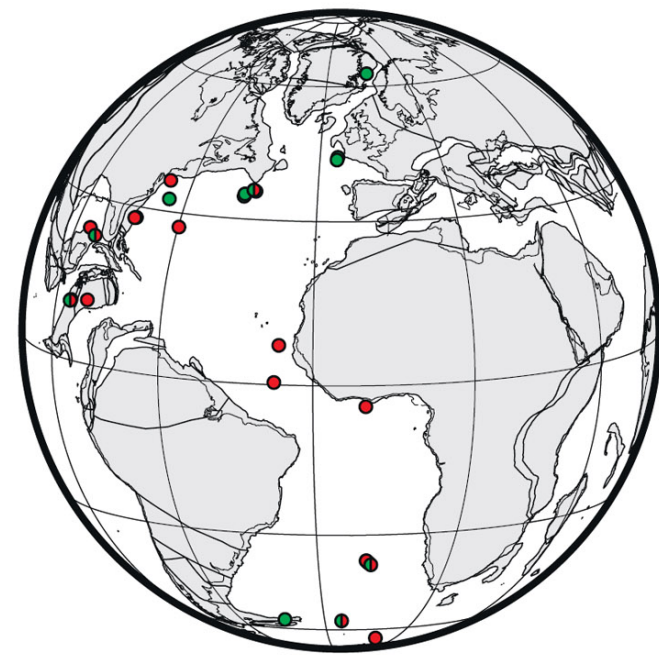

(C) 43-44 Ma, peak PBS

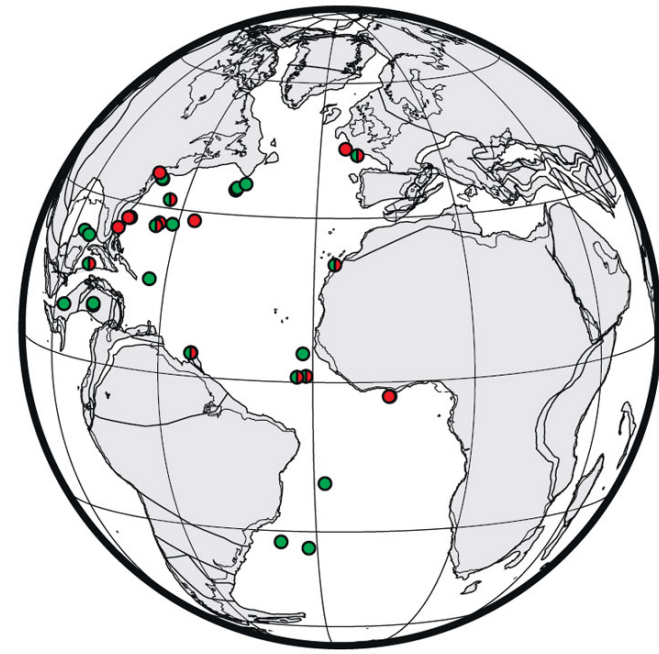

(B) 50-51 Ma, peak ISS

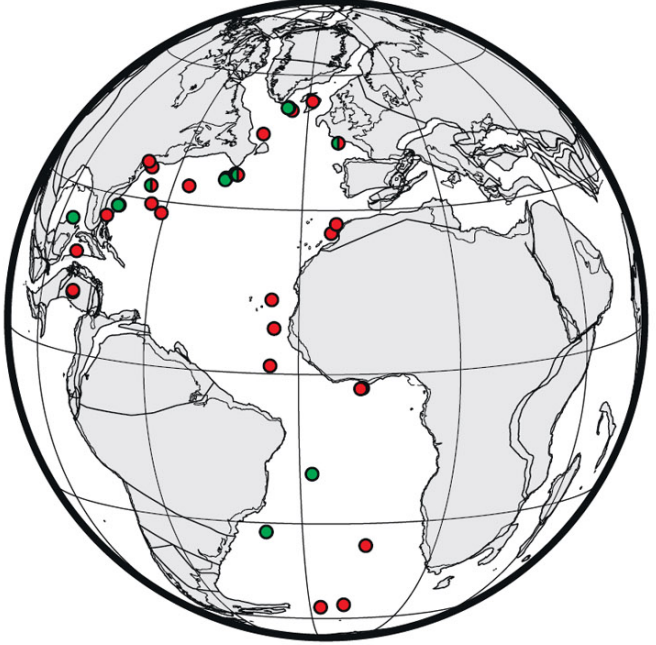

(D) 34-35 Ma, late Eocene

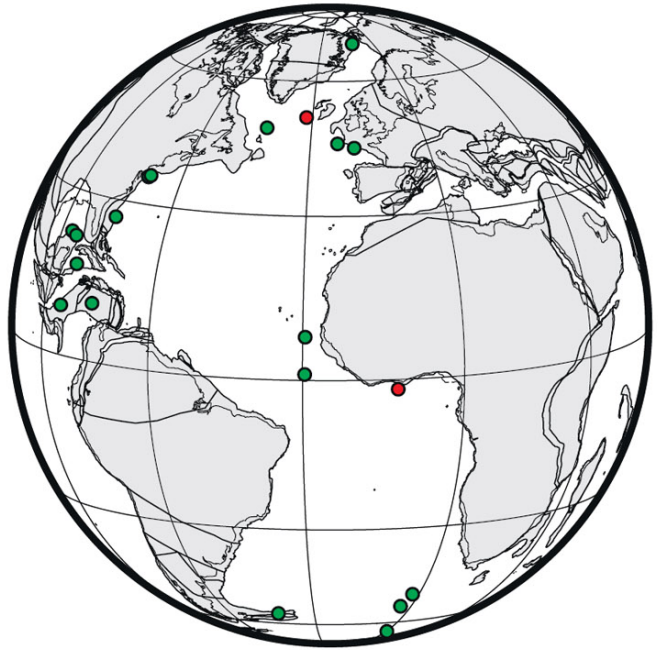

- Indurated Siliceous Sediment (ISS) occurrences

- Preserved Biosiliceous Sediment (PBS) occurrences

- ISS and PBS co-occurrences

Fig. 7. Paleogeographic shifts in siliceous sediment occurrences in the Atlantic Ocean for the late Paleocene (A), peak ISS frequency (B), peak PBS frequency (C), and before the Eocene-Oligocene Transition (D). For a complete set of paleogeographic maps see Fig. S3 in the online Supplementary Materials. Base maps plotted using Ocean Drilling Stratigraphic Network Advanced Plate Tectonic Reconstruction application. 
Another prominent $\mathrm{SiO}_{2}$ accumulation zone is the South Atlantic belt at $\sim 60^{\circ} \mathrm{S}$. The available evidence shows it was in existence from the earliest Paleocene to $\sim 54 \mathrm{Ma}$, from $\sim 52$ to $50 \mathrm{Ma}$, and again from $\sim 43 \mathrm{Ma}$ to $34 \mathrm{Ma}$ (Fig. S3). These breaks may represent periods of nonpreservation, but could also be due to plate tectonic reorganization associated with the Southern Ocean gateways opening (Egan et al., 2013, Borrelli et al., 2014).

Two other $\mathrm{P}+\mathrm{E}_{\text {bio }} \mathrm{SiO}_{2}$ accumulation zones are identified within the Atlantic Ocean (Fig. S3). The more persistent zone extended along the western coasts of Africa. By comparison to the modern realm, it was most likely associated with the equatorial divergence and coastal upwelling (Fig. S3). It appears to have undergone an extensive diagenetic alteration, as few sites within this zone preserve biosiliceous sediments, mostly within the middle through late Eocene time bins (e.g., Sites 13, 366, 367, 66o) (Fig. 7C-D, see also Fig. 2). The earliest siliceous deposits along African coasts are recorded at northern and southern midlatitude sites (e.g., Sites 530, 547) (Fig. S3). ${ }_{\text {bio }} \mathrm{SiO}_{2}$ accumulation at equatorial sites is not preserved until $\sim 6 \mathrm{o} \mathrm{Ma}$, which could result from non-preservation. From $\sim 60 \mathrm{Ma}$ on, however, the eastern equatorial Atlantic ${ }_{\text {bio }} \mathrm{SiO}_{2}$ accumulation zone persisted until the late Eocene (Fig. 7).

Southern mid-latitude ${ }_{\text {bio }} \mathrm{SiO}_{2}$ accumulation was mostly associated with upwelling over topographic elevations. $\mathrm{SiO}_{2}$ accumulation at Walvis Ridge (e.g., Sites 524-530, 1266) (Fig. 7A-B, Fig. S3) commenced at $\sim 61 \mathrm{Ma}$ and ceased at $\sim 54 \mathrm{Ma}$, with an additional brief pulse between $\sim 52$ and 50 Ma. From $\sim 54 \mathrm{Ma}$, southern mid-latitude ${ }_{\text {bio }} \mathrm{SiO}_{2}$ accumulation shifted in a northwestward direction, to Brazil Basin (Site 355), São Paulo Plateau (Site 356) and Rio Grande Rise (Site 357). These locations preserve biosiliceous sediments until $\sim 40$ Ma (Fig. $7 \mathrm{C}$ vs D, Fig. S3).

Following 30 myrs of gradual evolution, by the late Eocene, Atlantic ${ }_{\text {bio }} \mathrm{SiO}_{2}$ accumulation was focused in four zones: (1) NW, low- to mid-latitude sector; (2) NE, mid- to high-latitude sector; (3) E equatorial sector; and (4) S high latitude belt (Fig. 7D). Especially the latter zone seems to have undergone further evolution through the Oligocene and Neogene (Egan et al., 2013; Renaudie, 2016), to become one of the world's most significant ${ }_{\text {bio }} \mathrm{SiO}_{2}$ and C sinks (Fig. 7, Fig. S3). 


\section{Discussion}

\subsection{Atlantic Ocean ${ }_{b i o} \mathrm{SiO}_{2}$ accumulation versus terrestrial silicate weathering through the early Paleogene}

Silicon is mostly supplied to the oceans from continental weathering in the form of dissolved silicic acid, and the key output flux in the marine silicon cycle is ${ }_{b i o} \mathrm{SiO}_{2}$ production, export and burial (Tréguer and De La Rocha, 2013). Mass balance requires that the input be balanced by output, most likely on a $\sim 10^{4}$ year timescale (DeMaster, 1981), i.e., the residence time of $\mathrm{Si}$ in the oceans. Thus, the widespread occurrence of ISS in Paleogene successions, has been interpreted by some workers to signify elevated rates of Si supply to the oceans (e.g., Yool and Tyrrell, 2005). Under the extreme greenhouse climates of the early Paleogene, however, silicate supply to the oceans may have undergone periodic acceleration, whose impact on climate and ${ }_{b i 0} \mathrm{SiO}_{2}$ accumulation in marine settings is not yet fully understood (e.g., Caves et al., 2016; Van der Ploeg et al., 2018).

Despite the important implications of the links between C and Si cycles (see Penman, 2016; Penman et al., 2019), quantitative reconstructions of long-term ${ }_{\text {bio }} \mathrm{SiO}_{2}$ burial through the early Paleogene are sparse (e.g., Miskell et al., 1985; Moore et al., 2008) and therefore we have a limited perspective on the quantity and rate of Si supply to the oceans in deep time. Further, the vulnerability of ${ }_{\text {bio }} \mathrm{SiO}_{2}$ to dissolution, remineralization, and diagenetic alteration, (e.g., Ragueneau et al., 2000) all contribute to the fact that at present there is no straightforward way to relate ${ }_{\text {bio }} \mathrm{SiO}_{2}$ burial in deep time to variations in Si supply from continental weathering. As a consequence, our understanding of the silicate weathering thermostat operation under the extreme greenhouse climates of the early Paleogene, and especially its expression in siliceous sediments, is far from complete.

The modelled SWF (Caves et al., 2016) shows no straightforward correspondence to our ISS and PBS records. A peak in SWF appears to predate the peak in ISS occurrences by 1-2 myr, and there is no distinct feature in the SWF curve that could be confidently correlated with the PBS occurrences other than SWF deflection at $\sim 45 \mathrm{Ma}$. Taken at face value, these discrepancies could be interpreted to reflect some kind of long-term decoupling of the Si and C cycles through the early Paleogene. 
Despite rapid rates of early $\mathrm{SiO}_{2}$ diagenesis observed in laboratory experiments (e.g., Kastner et al., 1977), the present-day distribution of chert and porcellanite (Muttoni and Kent, 2007; Tatzel et al., 2015) suggests ISS formation lags the accumulation of the precursor sediment by several myrs. Also, as hypothesized above, early Paleogene PBS pool is most likely partially depleted due to ISS formation. Thus, the ISS and PBS records can only be considered a measure of geographic extent of a variety of siliceous facies and thus they do not necessarily evidence high rates of ${ }_{\text {bio }} \mathrm{SiO}_{2}$ burial. Blake Nose ${ }_{\text {bio }} \mathrm{SiO}_{2}$ concentration records (Witkowski et al., 2020b), however, are remarkably coherent with both the SWF model (Caves et al., 2016), and the ISS and PBS records presented here. This suggests that the discrepancies between the SWF curve (Caves et al., 2016) and the observations on biosiliceous sediments in the Atlantic Ocean result from model imperfections, incompleteness of the record due to extensive stratigraphic gaps (Aubry, 1995; Boyle et al., 2017; Witkowski et al., 2020a), or both.

\subsection{Western North Atlantic siliceous microfossil assemblages - the neritic paradox}

The key finding of the present study is that P+E ISS and PBS occurrences are generally restricted to proximal sites, adjacent to continental margins (Fig. 1A-B; Fig. S1). Regardless of upwelling, which is generally linked to the eastern coasts of the oceans, continental margins are among the areas of the highest modern diatom production due to nutrient supply from terrestrial runoff (Malviya et al., 2016; Abrantes et al., 2016). Yet, siliceous production on continental margins, including neritic sites, is usually neglected in paleoceanographic studies. This is due to a number of reasons, including age control uncertainties (e.g., Oreshkina and Aleksandrova, 2007) and the scarcity of geochemical data (see discussion in Witkowski, 2018). The present study emphasizes the need to reconsider the importance of marginal settings in the Paleogene ${ }_{\text {bio }} \mathrm{SiO}_{2}$ production and burial. This is best represented in the Blake Nose siliceous microfossil assemblages (Fig. 6), i.e., the only currently available single-locality record of ${ }_{\text {bio }} \mathrm{SiO}_{2}$ accumulation through almost the entire $\mathrm{P}+\mathrm{E}$ period.

Witkowski et al. (2014) reported unusually high percentages of neritic diatoms from a narrow interval spanning the MECO event in 
Holes 1051A and 1051B ( 41.5 through 39.5 Ma). High percentages of diatoms usually occurring in shelfal assemblages contrasted with the hemipelagic to pelagic setting of the Blake Nose sites. Fontorbe et al. (2016) suggested that the paleoecological assignments of Witkowski et al. (2014) may have been mistaken. Using data included in the Neptune Database (NSB), Fontorbe et al. (2016) cited the occurrences of neritic diatom genera at unquestionably pelagic sites, arguing for a habitat change over geological timescales. Depending on the methodology of studies incorporated into NSB (Lazarus, 1994; Renaudie et al., 2020), the database includes quantitative data only for some sites, and the prevalent qualitative data may only indicate the presence or absence of a taxon in a given deep-sea hole. Published diatom assemblage records testify to the contrary: since the Cretaceous, when diatoms first proliferated in marine environments, taxa such as Paralia and Pseudopodosira are abundant in near-shore environments (e.g., Barron et al., 1984; Witkowski et al., 2011), and sparse or absent in the pelagic realm (e.g., Davies, 2006; Witkowski et al., 2012). This strongly suggests that preference for habitat is a conservative trait in diatoms.

In the present study, in order to avoid interpreting diatom paleoecology based on poorly understood entirely fossil taxa, we limit our analysis to Paralia and Pseudopodosira. High Paralia+Pseudopodosira percentages are characteristic of the entire $\mathrm{P}+\mathrm{E}$ siliceous microfossil record at Blake Nose (Fig. 6C). Hence, we argue there is nothing unusual in sparse occurrences of neritic diatoms in pelagic sediments: tychoplanktic diatoms such as Paralia are known to be able to survive suspension by wave action, and even though they have a global distribution, their primary habitat is on sand grains within the littoral zone (Round et al., 1990; Gebühr et al., 2009). At Blake Nose, however, neritic diatoms consistently make up $\sim 66 \%$ of the diatom assemblage over the span of $\sim 30$ million years. Calcareous nannofossil assemblages at Blake Nose sites also show high proportion of braarudosphaerids (Newsam et al., 2017), indicating that enrichment in neritic component is not confined to diatoms.

Fontorbe et al. (2016) also cited lack of evidence for large-scale reworking or downslope movement of sediments draping Blake Nose. Although contribution from reworking and downslope transport could not be ruled out, the interpretation of Witkowski et al. (2014) invoked 
lateral currents as the medium responsible for the transport of neritic diatoms into the open ocean zone, following observations by Martin (2003). Such lateral currents are generated by cyclonic eddies, commonly observed in association with western boundary currents (Roughan et al., 2017). Along today's Blake Plateau, frontal eddies forming on the landward side of the Gulf Stream not only supply subthermocline nutrients to the continental shelf, but also provide an efficient means for offshore export of neritic phytoplankton (Lee et al., 1991). One alternative explanation for such high proportion of neritic diatoms in pelagic sediments could be preferential dissolution, which leads to selective concentration of heavily-silicified diatoms by dissolution of more fragile forms either at the sediment-water interface, or in transit through the water column (e.g., DeMaster, 2014). Preferential dissolution should be expected to favor preservation of radiolarians over diatoms, regardless of the degree of silicification. Yet, $\mathrm{D}: \mathrm{R}$ ratios for the time period 62-61 Ma range as high as 250, showing that the majority of ${ }_{\text {bio }} \mathrm{SiO}_{2}$ preserved in sediments is of diatom origin (Hollis et al., 1995; Renaudie et al., 2018). Low D:R ratios should be expected if the Blake Nose sediments were enriched in radiolarians due to preferential dissolution.

In their interpretation of trends in biosiliceous production through the MECO event, Witkowski et al. (2014) considered diatom production to be higher in the neritic rather than in the pelagic zone of the western North Atlantic Ocean. This is consistent not only with modern field observations, generally indicating nutrient-rich continental margins and upwelling zones as the key loci of diatom production, but also with fossil evidence from the eastern North American seaboard. Unaltered Paleogene diatom-rich sediments are scarce along the Atlantic coast. However, Weaver and Wise (1974), and Laws and Thayer (1992) presented compelling evidence for the diatomaceous origin of opaline claystones that are widespread on the Atlantic coastal plain, especially from the Tallahatta Fm. These sediments span calcareous nannofossil zones NP12-NP14 (Bybell and Gibson, 1985) (i.e., 53.7 through 46.3 Ma relative to GTS2012, see Fig. 3B), and thus are approximately correlative to peak ISS occurrence interval in the NW Atlantic. Further evidence for sustained high diatom production along the Gulf of Mexico coast comes from Fayette County marine diatomite exposures (Davis et al., 2016) that likely fall within nannofossil zone 
NP19-20 in the late Eocene ( 37 through 34.4 Ma in GTS2012; Fig. 3B). Finally, several holes drilled on the New Jersey rise and slope recovered shallow-water sediments that preserve late Eocene diatomrich sediments (e.g., Sites 612, 904 and 1073; see Table S1).

The Blake Nose diatom record offers insights into the composition of biosiliceous sediments preserved along the eastern margin of North America, and thus is an important supplement to the compilation of geographic and temporal distribution of the Atlantic P+E ISS and PBS. Using our siliceous microfossil data and published records from onshore and deep-sea sites, we argue that high ${ }_{\text {bio }} \mathrm{SiO}_{2}$ production at neritic sites is the key to understanding the ISS distribution in the Atlantic Ocean. Such scenario of neritic diatom production exceeding diatom production rates in the pelagic zone is consistent with present-day models (Malviya et al., 2016; Abrantes et al., 2016), but also with our current understanding of diatom evolution, with an invasion of pelagic environments only after the establishing of a successful neritic mode of life (Sims et al., 2006).

\subsection{Implications for paleocirculation}

One of the key questions surrounding the occurrence of early Paleogene ISS is why siliceous sediments tend to focus in the western North Atlantic. On one hand, the large concentration of siliceous facies could be an artifact related to the uneven geographic coverage of deep sea sites (Fig. S1, see also Supplementary Text). On the other hand, however, paleogeographic maps (Fig. 7 and Fig. S3), and published records (e.g., Berger, 1970; Miskell et al., 1985; Moore et al., 2008; Fontorbe et al., 2016) suggest ocean circulation may have been an important control.

The P+E NW Atlantic ${ }_{\text {bio }} \mathrm{SiO}_{2}$ accumulation belt (Fig. 7, Fig. S3) represents the most extensive and persistent zone of ISS and PBS occurrence examined here. The proto-Gulf Stream, which was likely in existence since the Jurassic (Gradstein and Sheridan, 1983; see also Pinet et al., 1981; Wade and Kroon, 2002) would have distributed dissolved $\mathrm{SiO}_{2}$ supplied from continental weathering (Penman, 2016; Penman et al., 2019), along with other nutrients, thus sustaining a high ${ }_{\text {bio }} \mathrm{SiO}_{2}$ production zone along the eastern margin of North America. For the deep waters bathing the eastern margin of North America, Fontorbe 
et al. (2016) postulate a probable Southern Ocean or Tethyan source. This is consistent with our paleogeographic compilation (Fig. 7, Fig. S3), showing that the $\mathrm{SiO}_{2}$ production and preservation zone generally propagated toward the NE, reaching a maximum extent by $\sim 50$ Ma, i.e., in the final phases of the EECO.

The NW Atlantic ${ }_{\text {bio }} \mathrm{SiO}_{2}$ accumulation zone started to diminish between $\sim 50$ and $49 \mathrm{Ma}$ (Fig. 7B, Fig. S3). Recent evidence suggests that at that time, subsidence of Greenland-Scotland Ridge enabled southwestward flow of young waters as a deep western boundary current (Hohbein et al., 2012). These water masses would have been highly $\mathrm{SiO}_{2}$-undersaturated and detrimental to ${ }_{\text {bio }} \mathrm{SiO}_{2}$ preservation, thus promoting ${ }_{\text {bio }} \mathrm{SiO}_{2}$ dissolution along their path in the western North Atlantic. This is consistent with the timing of ISS occurrences in Holes $1050 \mathrm{~A}$ and $1051 \mathrm{~A}$, but also with sedimentological evidence from the Blake Nose region. The prominent silicified interval in Hole 1051A (Fig. 5) consists of winnowed foraminiferal packstone indicative of a vigorous bottom current (Norris et al., 1998). The timing of the Northern Component Water (NCW) export is debated (Via and Thomas, 2006; Boyle et al., 2017; Coxall et al., 2018; Hutchinson et al., 2019), but the spatial and temporal distributions of $\mathrm{P}+\mathrm{E}$ ISS and PBS presented here strongly support an early flow of NCW as proposed by Hohbein et al. (2012). Thus, in a broader perspective, the widespread silicification of deep-sea sediments through the EECO may represent one of the aspects of deep-sea erosion documented at a large number of Atlantic deep-sea sites (Aubry, 1995), and linked by Hohbein et al. (2012) with the onset of Judd Falls Drift deposition in the North Atlantic.

A final aspect to consider in the discussion of siliceous sediments in the western North Atlantic is mass wasting. There is ample evidence for slope failures in the western North Atlantic in the early Paleogene (Norris et al., 2001). Siliceous turbidites, often associated with ISS, have been documented at numerous sites in the Bermuda Rise region (e.g., Sites 6-7, Sites 384-387; see Riech and von Rad, 1979). Slope failures would have periodically distributed the ${ }_{\text {bio }} \mathrm{SiO}_{2}$-rich sediments originally draping the continental slope over a large area of the seabed underneath generally oligotrophic waters in the pelagic zone of the western North Atlantic. Also, redeposition by gravity currents into the deep basin would re-expose ${ }_{\text {bio }} \mathrm{SiO}_{2}$-rich sediments to $\mathrm{SiO}_{2}$-undersaturated bottom waters and thus promote further dissolution and reprecipitation as ISS. 


\section{Conclusions}

The present study was initiated to test whether the widespread early Paleogene chert and porcellanite could have formed via inorganic precipitation under oligotrophic conditions in the oceans. Based on the consistent geographic patterns in ISS and PBS distribution (including numerous co-occurrences, not considered in previous work), and the generally inverse relationship between ISS and PBS distribution through time, we argue for a biogenic origin of the P+E ISS. Depending on the depositional setting, the biogenic precursors to chert and porcellanite underwent silicification either through exposure to $\mathrm{SiO}_{2}$-undersaturated waters at the sediment-water interface, facilitated by the generally low sedimentation rates through the early Eocene, or - conversely - through elevated temperatures and pressures due to rapid burial.

Biogenic origin of the ISS precursors has been difficult to reconcile with evidence for generally oligotrophic conditions prevailing in the Atlantic Ocean through the EECO. We document persistent, high ${ }_{\text {bio }} \mathrm{SiO}_{2}$ production on the North American shelf, and propose that offshore export, likely associated with Gulf Stream frontal eddies, was responsible for displacing neritic diatoms into the pelagic zone of the western North Atlantic Ocean. An early southward flow of nutrient depleted NCW facilitated dissolution of ${ }_{b i o} \mathrm{SiO}_{2}$-rich sediments along the North American continental margin. Thus, the prolonged supply of ${ }_{b i-}$ $\mathrm{SiO}_{2}$ from the North American margin coupled with plate tectonic reorganization that resulted in changes to circulation patterns contributed to widespread silicification in lower Eocene sediments despite the prevailing oligotrophic surface water conditions. Even if this model does not apply to NE and S Atlantic ISS occurrences, it does help explain why chert and porcellanite are so prolific in the Gulf of Mexico, the Caribbean, and along the eastern North American margin.

Our study shows that the distribution of Early Cenozoic siliceous sediments in the Atlantic Ocean was influenced by an interplay of tectonics, climate, ocean circulation, and ${ }_{\text {bio }} \mathrm{SiO}^{2}$ production and diagenesis. The interpretation of early Paleogene siliceous sedimentation in the Atlantic Ocean presented here is simpler than the inorganic origin hypothesis. It is also consistent with micropaleontological evidence, well-established views on ${ }_{\text {bio }} \mathrm{SiO}_{2}$ diagenesis, and finally - with 
the current understanding of the ocean's biogeochemical evolution through the late Mesozoic and Cenozoic, which suggests that diatom proliferation contributed to a global dissolved silicate drawdown before the $\mathrm{K} / \mathrm{Pg}$ event, making precipitation of $\mathrm{SiO}_{2}$ from seawater highly unlikely.

Acknowledgments This study was supported by grant no. 2014/13/B/ST10/02988, awarded by the National Science Centre (Poland). Kevin McCartney and Jörn Thiede are thanked for kindly donating their sets of DSDP and ODP volumes to the Institute of Marine and Environmental Sciences at University of Szczecin, which greatly facilitated this work. We gratefully acknowledge the detailed comments by the editor Thomas Algeo, and insightful reviews by Johan Renaudie and one anonymous reviewer.

Competing Interest The authors declare that they have no known competing financial interests or personal relationships that could have appeared to influence the work reported in this paper.

Supplementary materials Appendix A (109 pages, .pdf) and a spreadsheet (2 pages, .xls) are attached to the main archive record for this article.

\section{References}

Abrantes, F., Cermeno, P., Lopes, C., Romero, O., Matos, L., Van Iperen, J., Rufino, M., Magalhães, V., 2016. Diatoms Si uptake capacity drives carbon export in coastal upwelling systems. Biogeosciences 13, 4099-4109.

Anagnostou, E., John, E.H., Edgar, K.M., Foster, G.L., Ridgwell, A., Inglis, G.N., Pancost, R.D., Lunt, D.J., Pearson, P.N., 2016. Changing atmospheric $\mathrm{CO} 2$ concentration was the primary driver of early Cenozoic climate. Nature 533, 380-384.

Aubry, M.-P., 1995. From chronology to stratigraphy: Interpreting the lower and middle Eocene stratigraphic record in the Atlantic Ocean. In: Berggren, W.A., Kent, D.V., Aubry, M.-P., Hardenbol, J. (Eds.), Geochronology, Time Scales, and Global Stratigraphic Correlation. SEPM Special Publication, vol. 54. pp. 213-274.

Baldauf, J.G., Barron, J.A., 1990. Evolution of biosiliceous sedimentation patterns - eocene through quaternary: paleoceanographic response to polar cooling. In: Bleil, U., Thiede, J. (Eds.), Geological History of the Polar Oceans: Arctic versus Antarctic, pp. 575-607.

Barron, J.A., Bukry, D., Poore, R.Z., 1984. Correlation of the middle Eocene Kellogg Shale of northern California. Micropaleontology 30, 138-170. 
Barron, J.A., Stickley, C.E., Bukry, D., 2015. Paleoceanographic, and paleoclimatic constraints on the global Eocene diatom and silicoflagellate record. Palaeogeogr. Palaeoclimatol. Palaeoecol. 422, 85-100.

Berger, W.H., 1970. Biogenous deep-sea sediments: fractionation by deep-sea circulation. Geol. Soc. Am. Bull. 81, 1385-1402.

Bohaty, S.M., Zachos, J.C., Florindo, F., Delaney, M.L., 2009. Coupled greenhouse warming and deep-sea acidification in the middle Eocene. Paleoceanography 24, PA2207.

Borrelli, C., Cramer, B.S., Katz, M.E., 2014. Bipolar Atlantic Deepwater circulation in the middle-late Eocene: effects of Southern Ocean gateway openings. Paleoceanography 29, 308-327.

Boyle, P.R., Romans, B.W., Tucholke, B.E., Norris, R.D., Swift, S.A., Sexton, P.F., 2017. Cenozoic North Atlantic deep circulation history recorded in contourite drifts, offshore Newfoundland, Canada. Mar. Geol. 385, 185-203.

Bybell, L.M., Gibson, T.G., 1985. The Eocene Tallahatta Formation of Alabama and Georgia; its lithostratigraphy, biostratigraphy, and bearing on the age of the Claibornian Stage. U.S. Geol. Surv. Bull. 1615, 1-20.

Calvert, S.E., 1977. Mineralogy of silica phases in deep-sea cherts and porcelanites. Phil. Trans. R. Soc. A 286, 239-252.

Caves, J.K., Jost, A.B., Lau, K.V., Maher, H., 2016. Cenozoic carbon cycle imbalances and a variable weathering feedback. Earth Planet. Sci. Lett. 450, 152-163.

Conley, D.J., Frings, P.J., Fontorbe, G., Clymans, W., Stadmark, J., 2017. Biosilicification drives a decline of dissolved $\mathrm{Si}$ in the oceans through geologic time. Front. Mar. Sci. 4, 397.

Coxall, H.K., Huck, C.E., Huber, M., Lear, C.H., Legarda-Lisarri, A., O’Regan, M., Śliwińska, K.K., de Flierdt, T., de Boer, A.M., Zachos, J.C., Backman, J., 2018. Export of nutrient rich Northern Component Water preceded early Oligocene Antarctic glaciation. Nat. Geosci. 11, 190-196.

Cramer, B.S., Toggweiler, J.R., Wright, J.D., Katz, M.E., Miller, K.G., 2009. Ocean overturning since the late cretaceous: inferences from a new benthic foraminiferal isotope compilation. Paleoceanography 24, PA4216.

Cramwinckel, M.J., Huber, M., Kocken, I.J., Agnini, C., Bijl, P.K., Bohaty, S.M., Frieling, J., Goldner, A., Hilgen, F.J., Kip, E.L., Peterse, F., van der Ploeg, R., Röhl, U., Schouten, S., Sluijs, A., 2018. Synchronous tropical and polar temperature evolution in the Paleocene. Nature 559, 382-386.

Cramwinckel, M.J., van der Ploeg, R., Bijl, P.K., Peterse, F., Bohaty, S.M., Röhl, U., Schouten, S., Middelburg, J.J., Sluijs, A., 2019. Harmful algae and export production collapse in the equatorial Atlantic during the zenith of Middle Eocene Climatic Optimum warmth. Geology 47, 247-250.

Davies, A., 2006. High Resolution Palaeoceanography and Palaeoclimatology from Mid and High Latitude Late Cretceous Laminated Sediments. Unpublished PhD dissertation. University of Southampton (274 pp).

Davis, S.L., Mohandas, S., Nzoumba, G.G., Yancey, T.E., 2016. Diatomite in Upper Eocene Jackson Group, Fayette County, Texas. Gulf Coast Association of Geological Societies Transactions 66, 739-746. 
DeMaster, D.J., 1981. The supply and accumulation of silica in the marine environment. Geochimica and Cosmochimica Acta 45, 1715-1732.

DeMaster, D.J., 2014. The diagenesis of biogenic silica: Chemical transformations occurring in the water column, seabed, and crust. In: Holland, H.D., Turekian, K.K. (Eds.), Treatise on Geochemistry, 2nd edition. vol. 9. pp. 103-111.

Dinarès-Turell, J., Pujalte, V., Stoykova, K., Baceta, J.I., Ivanov, M., 2012. The Palaeocene "top chron C27n" transient greenhouse episode: evidence from marine pelagic Atlantic and peri-Tethyan sections. Terra Nova 24, 477-486.

Edgar, K.M., Wilson, P.A., Sexton, P.F., Suganuma, Y., 2007. No extreme bipolar glaciation during the main Eocene calcite compensation shift. Nature 448, 908-911.

Egan, K.E., Rickaby, R.E.M., Hendry, K.R., Halliday, A.N., 2013. Opening the gateways for diatoms primes Earth for Antarctic glaciation. Earth Planet. Sci. Lett. 375, 34-43.

Ewing, J., Windisch, C., Ewing, M., 1970. Correlation of Horizon a with Joides bore-hole results. J. Geophys. Res. 75, 5645-5653.

Fontorbe, G., Frings, J., De La Rocha, C.L., Hendry, K.R., Conley, D.J., 2016. A silicon depleted North Atlantic since the Palaeogene: evidence from sponge and radiolarian silicon isotopes. Earth Planet. Sci. Lett. 453, 67-77.

Fontorbe, G., Frings, J., De La Rocha, C.L., Hendry, K.R., Conley, D.J., 2020. Constraints on Earth System functioning at the Paleocene-Eocene thermal Maximum from the marine silicon cycle. Paleoceanography and Paleoclimatology 35 (e2020PAoo3873).

Foster, G.L., Royer, D.L., Lunt, D.J., 2017. Future climate forcing potentially without precedent in the last 420 million years. Nat. Commun. 8, 14845.

Fourtanier, E., 1991. Paleocene and Eocene Diatom Biostratigraphy and Taxonomy of Eastern Indian Ocean Site 752. Proceedings of the Ocean Drilling Program 121, 171-187.

Frings, P., 2017. Revisiting the dissolution of biogeic Si i marine sediments: a key term in the ocean Si budget. Acta Geochimica 36, 429-432.

Gebühr, C., Wiltshire, K.H., Aberle, N., van Beusekom, J.E.E., Gerdts, G., 2009. Influence of nutrients, temperature, light and salinity on the occurrence of Paralia sulcata at Helgoland roads, North Sea. Aquat. Biol. 7, 185-197.

Gibson, T.G., Towe, K.M., 1971. Eocene Volcanism and the Origin of Horizon A. Science 172, 152-154.

Gombos, A.M., 1977. Paleogene and Neogene Diatoms from the Falkland Plateau and Malvinas Outer Basin: Leg 36, Deep Sea Drilling Project. Initial Reports of the Deep- Sea Drilling Project 36, 575-687.

Gradstein, F.M., Sheridan, R.E., 1983. On the Jurassic Atlantic Ocean and a synthesis of results of deep sea drilling project Leg 76 . Initial Reports of the Deep-Sea Drilling Project 76, 913-943.

Gradstein, F.M., Ogg, J.G., Schmitz, M.D., Ogg, G.M., 2012. The Geologic Time Scale 2012. Elsevier, Amsterdam (2 Vols, 1144 pp). 
Hein, J.R., Parrish, J.T., 1987. Distribution of siliceous deposits in space and time. In: Hein, J.R. (Ed.), Siliceous Sedimentary Rock-Hosted Ores and Petroleum. Van Nostrand Reinhold Company, Inc, New York, pp. 10-57.

Hein, J.R., Yeh, H.-W., Barron, J.A., 1990. Eocene diatom chert from Adak Island, Alaska. J. Sediment. Res. 6o, 250-257.

Hesse, R., 1983. Diagnesis \#13. Origin of chert: diagenesis of biogenic siliceous sediments. Geosci. Can. 15, 171-192.

Hohbein, M.W., Sexton, P.F., Cartwright, J.A., 2012. Onset of North Atlantic Deep Water production coincident with inception of the Cenozoic global cooling trend. Geology 40, 255-258.

Hollis, C.J., Rodgers, K.A., Parker, R.J., 1995. Siliceous plankton bloom in the earliest Tertiary of Marlborough, New Zealand. Geology 23, 835-858.

Hutchinson, D.K., Coxall, H.K., O’Regan, M., Nilsson, J., Caballero, R., de Boer, A.M., 2019. Arctic closure as a trigger for Atlantic overturning at the EoceneOligocene transition. Nat. Commun. 10, 3797.

Kamikuri, S., Wade, B.S., 2012. Radiolarian magnetobiochronology and faunal turnover across the middle/late Eocene boundary at Ocean Drilling Program Site 1052 in the western North Atlantic Ocean. Mar. Micropaleontol. 88-89, 41-53.

Kastner, M., Keene, J.B., Gieskes, J.M., 1977. Diagenesis of siliceous oozes I. Chemical controls on the rate of opal-A to opal-CT transformation - an experimental study. Geochimica and Cosmochimica Acta 41 (1041-1051), 1053-1059.

Kemp, A.E.S., Villareal, T.A., 2018. The case of the diatoms and the muddled mandalas: time to recognize diatom adaptations to stratified waters. Prog. Oceanogr. 167, 138-149.

Kennett, J.P., 1982. Marine Geology. Prentice-Hall, Englewood Cliffs, N.J (813 pp).

Laws, R.A., Thayer, P.A., 1992. Origin and diagenesis of middle Eocene diatomite, Tallahatta Formation, Southwest Alabama. Transactions of the Gulf Coast Association of Geological Societies 42, 517-527.

Lazarus, D., 1994. Neptune: a marine micropaleontology database. Math. Geol. 26, 817-832.

Lee, T.N., Yoder, J.A., Atkinson, L.P., 1991. Gulf Stream frontal eddy influence on productivity of the southeast U.S. continental shelf. J. Geophys. Res. 96, 22191-22205.

Luciani, V., Dickens, G.R., Backman, J., Fornaciari, E., Giusberti, L., Agnini, C., D'Onoforio, R., 2016. Major perturbations in the global carbon cycle and photosymbiont- bearing planktic foraminifera during the early Eocene. Clim. Past 12, 981-1007.

Mach, K., Dvořák, Z., 2011. Geology of the site Kučlin, Trupelník Hill near Bílina in North Bohemia. Sborník Národního Muzea v Praze, Řada B - PŘírodní vědy 67, 77-82.

Maldonado, M., Carmona, M.C., Uriz, M.J., Cruzado, A., 1999. Decline in Mesozoic reef-building sponges explained by silicon limitation. Nature 401, 785-788. 
Maliva, R.G., Knoll, A.H., Siever, R., 1989. Secular change in chert distribution: a reflection of evolving biological participation in the silica cycle. Palaios 4 , 519-532.

Malviya, S., Scalco, E., Audic, S., Vincent, F., Veluchamy, A., Poulain, J., Wincker, P., Iudicone, D., de Vargas, C., Bittner, L., Zingone, A., Bowler, C., 2016. Insights into global diatom distribution and diversity in the world's ocean. Proc. Natl. Acad. Sci. U. S. A. 113, E1516-E1525.

Martin, A.P., 2003. Phytoplankton patchiness: the role of lateral stirring and mixing. Prog. Oceanogr. 57, 125-174.

McGowran, B., 1989. Silica burp in the Eocene Ocean. Geology 17, 857-860.

Miskell, K.J., Brass, G.W., Harrison, C.G.A., 1985. Global patterns in opal deposition from late cretaceous to late Miocene. The American Association of Petroleum Geologists Bulletin 69, 996-1012.

Moore, T.C., 2008a. Biogenic silica and chert in the Pacific Ocean. Geology 36, 975-978.

Moore, T.C., 2008b. Chert in the Pacific: Biogenic silica and hydrothermal circulation. Palaeogeogr. Palaeoclimatol. Palaeoecol. 261, 87-99.

Moore, T.C., Jarrard, R.D., Olivarez Lyle, A., Lyle, M., 2008. Eocene biogenic silica accumulation rates at the Pacific equatorial divergence zone. Paleoceanography 32, PA22O2.

Muttoni, G., Kent, D.V., 2007. Widespread formation of cherts during the early Eocene climate optimum. Palaeogeogr. Palaeoclimatol. Palaeoecol. 253, 348-362.

Newsam, C., Bown, P.R., Wade, B.S., Jones, H.L., 2017. Muted calcareous nannofossil response at the middle/late Eocene turnover event in the western North Atlantic Ocean. Newsl. Stratigr. 50, 297-309.

Nishimura, A., 1987. Cenozoic Radiolaria in the Western North Atlantic, Site 603, Leg 93 of the Deep Sea Drilling Project. Initial Rep. Deep Sea Drill. Proj. 93, 713-731.

Norris, R.D., Kroon, D., et al., 1998. Site 1051. Proceedings of the Ocean Drilling Program, Initial Reports 171B, 171-239.

Norris, R.D., Kroon, D., Huber, B.T., Erbacher, J., 2001. Cretaceous-Palaeogene Ocean and climate change in the subtropical North Atlantic. In: Kroon, D., Norris, R.D., Klaus, A. (Eds.), Western North Atlantic Palaeogene and Cretaceous Palaeoceanography. Geological Society, London, Special Publications, vol. 183. pp. 1-22.

Oreshkina, T.V., Aleksandrova, G.N., 2007. Terminal Paleocene of the Volga middle reaches: Biostratigraphy and paleosettings. Stratigr. Geol. Correl. 15, 206-230.

Penman, D., 2016. Silicate weathering and North Atlantic silica burial during the Paleocene-Eocene thermal Maximum. Geology 44, 731-734.

Penman, D., Keller, A., D’haenens, S., Turner, S.K., Hull, P.M., 2019. Atlantic deepsea cherts associated with eocene hyperthermal events. Paleoceanography and Paleoclimatology 34, 287-299. 
Pinet, P.R., Popenoe, P., Nelligan, D.F., 1981. Gulf Stream: reconstruction of Cenozoic flow patterns over the Blake Plateau. Geology 9, 266-270.

Ragueneau, O., Tréguer, P., Leynaert, A., Anderson, R.F., Brzezinski, M.A., DeMaster, D.J., Dugdale, R.C., Dymond, J., Fischer, G., François, R., Heinze, C., Maier-Reimer, E., Martin-Jézéquel, V., Nelson, D.M., Quéguiner, B., 200o. A review of the Si cycle in the modern ocean: recent progress and missing gaps in the application of biogenic opal as a paleoproductivity proxy. Glob. Planet. Chang. 26, 317-365.

Renaudie, J., 2016. Quantifying the Cenozoic marine diatom deposition history: links to the C and Si cycles. Biogeosciences 13, 6003-6014.

Renaudie, J., Drews, E.-L., Böhne, S., 2018. The Paleocene record of marine diatoms in deep-sea sediments. Fossil Record 21, 183-205.

Renaudie, J., Lazarus, D.B., Diver, P., 2020. NSB (Neptune Sandbox Berlin): an expanded and improved database of marine planktonic microfossil data and deep-sea stratigraphy. Palaeontol. Electron. 23, a11.

Riech, V., von Rad, U., 1979. Eocene porcellanites and early cretaceous cherts from the western North Atlantic basin. Initial Rep. Deep Sea Drill. Proj. 43, 437-457.

Roughan, M., Keating, S.R., Schaeffer, A., Cetina Heredia, P., Rocha, C., Griffin, D., Robertson, R., Suthers, M., 2017. A tale of two eddies: the biophysical characteristics of two contrasting cyclonic eddies in the East Australian Current System. Journal of Geophysical Research: Oceans 122, 2494-2518.

Round, F.E., Crawford, R.M., Mann, D.G., 1990. The Diatoms. Biology and Morphology of the Genera. Cambridge University Press, Cambridge (747 pp).

Sims, P.A., Mann, D.G., Medlin, L.K., 2006. Evolution of the diatoms: insights from fossil, biological and molecular data. Phycologia 45, 361-402.

Tatzel, M., von Blackenburg, F., Oelze, M., Schuessler, J.A., Bohrmann, G., 2015. The silicon isotope record of early silica diagenesis. Earth Planet. Sci. Lett. 428, 293-303.

Tréguer, P.J., De La Rocha, C.L., 2013. The world ocean silica cycle. Annu. Rev. Mar. Sci. 5, 477-501.

Vahlenkamp, M., Niezgodzki, I., De Vleeschouwer, D., Bickert, T., Harper, D., Kirtland Turner, S., Lohmann, G., Sexton, P., Zachos, J., Pälike, H., 2018. Astronomically paced changes in deep-water circulation in the western North Atlantic during the middle Eocene. Earth Planet. Sci. Lett. 484, 329-340.

Van Cappellen, P., Dixit, S., van Beusekom, J., 2002. Biogenic silica dissolution in the oceans: reconciling experimental and field-based dissolution rates. Glob. Biogeochem. Cycles 16, 1075.

Van der Ploeg, R., Selby, D., Cramwinckel, M.J., Li, Y., Bohaty, S., Middelburg, J.J., Sluijs, A., 2018. Middle Eocene greenhouse warming facilitated by diminished weathering feedback. Nat. Commun. 9, 2877.

Via, R.K., Thomas, D.J., 2006. Evolution of Atlantic thermohaline circulation: early Oligocene onset of deep-water production in the North Atlantic. Geology 34, 441-444. 
Wade, B.S., Kroon, D., 2002. Middle Eocene regional climate instability: evidence from the western North Atlantic. Geology 30, 1011-1014.

Wade, B.S., O'Neill, J.F., Phujareanchaiwon, C., Ali, I., Witkowski, J., 2020. Evolution of deep-sea sediments across the Paleocene-Eocene and EoceneOligocene boundaries. Earth-Science Reviews (Under review).

Weaver, F.M., Wise, S.W., 1974. Opaline sediments of the Southeastern Coastal plain and horizon A: Biogenic Origin. Science 184, 899-901.

Westerhold, T., Röhl, U., Donner, B., Zachos, J.C., 2018. Global extent of early eocene hyperthermal events: a New Pacific Benthic Foraminiferal Isotope Record from Shatsky rise (ODP Site 1209). Paleoceanography and Paleoclimatology 33, 626-642.

Witkowski, J., 2018. From museum drawers to ocean drilling: Fenneria gen. nov. (Bacillariophyta) offers new insights into Eocene marine diatom biostratigraphy and palaeobiogeography. Acta Geol. Pol. 68, 53-88.

Witkowski, J., Harwood, D.M., Chin, K., 2011. Taxonomic composition, paleoecology and biostratigraphy of late cretaceous diatoms from Devons Island, Nunavut, Canadian High Arctic. Cretac. Res. 32, 277-300.

Witkowski, J., Bohaty, S.M., McCartney, K., Harwood, D.M., 2012. Enhanced siliceous plankton productivity in response to middle Eocene warming at Southern Ocean ODP Sites 748 and 749. Palaeogeogr. Palaeoclimatol. Palaeoecol. 326-328, 78-94.

Witkowski, J., Bohaty, S.M., Edgar, K.M., Harwood, D.M., 2014. Rapid fluctuations in mid-latitude siliceous plankton production during the Middle Eocene Climatic Optimum (ODP Site 1051, western North Atlantic). Mar. Micropaleontol. 106, 110-129.

Witkowski, J., Harwood, D.M., Wade, B.S., Bryłka, K., 2020a. Rethinking the chronology of early Paleogene sediments in the western North Atlantic Ocean using diatom biostratigraphy. Mar. Geol. 424, 106168.

Witkowski, J., Penman, D.E., Bryłka, K., Wade, B.S., Bohaty, S.M., 202ob. Controls on Western North Atlantic Marine Biogenic Opal Accumulation Through the Early Paleogene. (Submitted to GSA Bulletin, Under review).

Yool, A., Tyrrell, T., 2005. Implications for the history of Cenozoic opal deposition from a quantitative model. Palaeogeogr. Palaeoclimatol. Palaeoecol. 218, 239-255.

Zachos, J.C., Pagani, M., Sloan, L., Thomas, E., Billups, K., 2001. Trends, Rhythms, and Aberrations in Global climate 65 Ma to present. Science 292, 686-693.

Zachos, J.C., Dickens, G.R., Zeebe, R.E., 2008. An early Cenozoic perspective on greenhouse warming and carbon-cycle dynamics. Nature 451, 279-283. 